\title{
Nitrogen fixation, uptake and metabolism in natural and cultured populations of Trichodesmium spp.
}

\author{
Margaret R. Mulholland*, Douglas G. Capone** \\ Chesapeake Biological Laboratory, University of Maryland Center for Environmental Science, PO Box 38, Solomons, \\ Maryland 20688, USA
}

\begin{abstract}
Uptake rates of several combined $N$ sources, $N_{2}$ fixation, intracellular glutamate (glu) and glutamine (gln) pools, and glutamine synthetase (GS) activity were measured in natural populations and a culture of Trichodesmium IMS101 grown on seawater medium without added N. In cultured populations, the ratio of GS transferase/biosynthetic activity (an index of the proportion of the GS pool that is active) was lower, and intracellular pools of glu and gln and the ratios of $\mathrm{gln} / \mathrm{glu}$ and $\mathrm{gln} / \alpha$ ketoglutarate $(g \ln / \alpha \mathrm{kg})$ ratios were higher when $\mathrm{N}_{2}$ fixation was highest (mid-day). There was an excess capacity for $\mathrm{NH}_{4}{ }^{+}$assimilation via GS, indicating that this was not the rate-limiting step in $\mathrm{N}$ utilization. In natural populations of Trichodesmium spp., the gln/glu ratio closely approximated the gln/akg ratio over the diel cycle. High gln/glu and gln/ $\alpha \mathrm{kg}$ ratios were noted in near-surface populations. These ratios decreased in samples collected from greater depths. Natural populations of $T r i$ chodesmium spp. showed a high capacity for the uptake of $\mathrm{NH}_{4}{ }^{+}$, glu, and mixed amino acids (AA). Rates of $\mathrm{NO}_{3}{ }^{-}$and urea uptake were low. $\mathrm{NH}_{4}{ }^{+}$accumulated in the culture medium during growth and rates of $\mathrm{NH}_{4}{ }^{+}$uptake showed a positive relationship with the $\mathrm{NH}_{4}{ }^{+}$concentration in the medium. Although rates of $\mathrm{N}_{2}$ fixation were highest and accounted for the majority of the total measured $\mathrm{N}$ utilization during mid-day, rates of $\mathrm{NH}_{4}{ }^{+}$uptake exceeded rates of $\mathrm{N}_{2}$ fixation throughout much of the diel cycle. In exponentially growing cultures, only $23 \%$ of the total daily $\mathrm{N}$ utilization was due to $\mathrm{N}_{2}$ fixation while $\mathrm{NH}_{4}{ }^{+}$uptake accounted for more than $70 \%$. Based on $\mathrm{N}_{2}$ fixation alone, the $\mathrm{N}$ turnover time for this culture during exponential growth was on the order of $9 \mathrm{~d}$. This is consistent with the observed chlorophyll-based growth rates for these cultures suggesting that $\mathrm{N}_{2}$ fixation was responsible for net growth. Our results contrast with the view that natural populations of Trichodesmium spp. acquire their cell $\mathrm{N}$ exclusively through $\mathrm{N}_{2}$ fixation. C productivity may overestimate $\mathrm{N}$ demand for net production if regenerated production is significant in these populations.
\end{abstract}

KEY WORDS: Trichodesmium $\cdot$ Nitrogen metabolism $\cdot \mathrm{N}_{2}$ fixation $\cdot$ Amino acid pools $\cdot$ Nitrogen uptake

\section{INTRODUCTION}

Trichodesmium spp. are common throughout the tropical and subtropical oligotrophic ocean (Capone et al. 1997). They occur as free trichomes or as colonial

Present addresses:

- Marine Sciences Research Center, SUNY Stony Brook,

Stony Brook, New York 11794-5000, USA.

E-mail: mmulholland@notes.cc.sunysb.edu

- Department of Biological Sciences, University of Southern

California, Los Angeles, California 90089, USA aggregates that are spherical (puffs) or fusiform (tufts). Colonies and free trichomes are capable of fixing $\mathrm{N}_{2}$, which allows them to alleviate $N$ limitation in the seas in which they occur.

In natural populations of Trichodesmium thiebautil nitrogenase synthesis and activity exhibit a daily cycle (Capone et al. 1990, Zehr et al. 1993). Nitrogenase, the enzyme complex responsible for catalyzing the reduction of $\mathrm{N}_{2}$, activity is confined to the daylight hours and rates of $\mathrm{N}_{2}$ fixation are highest around mid-day, suggesting that light or photosynthesis might regulate nitrogenase activity (Saino \& Hattori 1978, Capone et 
al. 1990). Chen et al. (1996) established in cultures of Trichodesmium IMS101 that this cycle is driven by an endogenous rhythm.

$\mathrm{N}$ metabolism in natural populations of Trichodesmium spp. has been shown to proceed via the glutamine synthetase (GS)/glutamate synthase (GOGAT) pathway (Carpenter et al. 1992), as for most diazotrophic cyanobacteria. GS activity was measured in populations of Trichodesmium spp. from the North Atlantic using the transferase assay. Rates did not vary significantly over a diel cycle although concentrations of GS protein were positively correlated with concentrations of nitrogenase protein in immuno-labeling studies (Carpenter et al. 1992). Cellular nitrogenase and GS concentrations both declined at night when cells were not fixing $\mathrm{N}_{2}$.

Little is known about the growth cycle, the physiological status or the regulation of $\mathrm{N}_{2}$ fixation in natural populations of Trichodesmium spp. The glutamine/glutamate (gln/glu) ratio has been used as an index of N-status in phytoplankton and cyanobacteria (Flynn et al. 1989, Flynn 1990, Flynn \& Gallon 1990). Capone et al. (1994) found that intracellular glu and gln concentrations and the ratio of $\mathrm{gln} / \mathrm{glu}$ varied on a diel basis in Trichodesmium spp., in parallel with the pattern of $\mathrm{N}_{2}$ fixation.

$\mathrm{N}_{2}$ fixation is generally held to be the primary mode of $\mathrm{N}$ acquisition for these species in nature (Carpenter \& McCarthy 1975, Mague et al. 1977, Carpenter 1983b، Carpenter et al. 1997). While surface waters in the tropical oligotrophic ocean gyres are generally depleted in combined $\mathrm{N}_{1} \mathrm{NH}_{4}^{+}$and dissolved organic $\mathrm{N}$ (DON) are rapidly recycled to support much of the apparent $\mathrm{N}$ demand of primary production in these systems (Eppley \& Peterson 1979, Bronk et al. 1994). Trichodesmium spp. contributes directly to $\mathrm{NH}_{4}^{+}$turnover in these systems by its release of amino acids (AA), DON, and possibly $\mathrm{NH}_{4}{ }^{+}$(Capone et al. 1994, Glibert \& Bronk 1994, O'Neil et al. 1996). During oceanic blooms of Trichodesmium, dissolved $\mathrm{N}$ pools can become elevated as a result of recent $\mathrm{N}$ input (Devassy 1987, Karl et al. 1992). Based on these observations and the energy requirements for $\mathrm{N}_{2}$ fixation, the absence of a capacity for the uptake of reduced $\mathrm{N}$ by Trichodesmium spp. seems enigmatic.

There is evidence that Trichodesmium spp. are capable of taking up combined $\mathrm{N}$ (e.g. $\mathrm{NH}_{4}{ }^{+}, \mathrm{NO}_{3}{ }^{-}$, DON). Natural populations of Trichodesmium spp. were shown to have a capacity to take up $\mathrm{NH}_{4}{ }^{+}, \mathrm{NO}_{3}{ }^{-}$, and urea in the Northwest Pacific (Saino 1977, Saino \& Hattori 1978) and in the tropical North Atlantic (Goering et al. 1966). In contrast, very low rates of $\mathrm{NH}_{4}{ }^{+}$, $\mathrm{NO}_{3}{ }^{-}$, and urea uptake were reported for populations from the North Atlantic Ocean and the Caribbean Sea (Carpenter \& McCarthy 1975, Glibert \& Banahan
1988). A capacity for glu and gln uptake by colonial aggregates was demonstrated in natural populations of Trichodesmium spp. (Saino 1977. Carpenter et al. 1992, Capone et al. 1994).

We therefore examined the ability of Trichodesmium to assimilate combined $\mathrm{N}$ in cultures grown on medium without added $\mathrm{N}$ and in natural populations in order to evaluate the generalization that they are wholly dependent upon $\mathrm{N}_{2}$ fixation and also to understand how the observed patterns of nitrogenase synthesis, activity and modification are regulated. Both the $\mathrm{gln} / \mathrm{glu}$ ratio and the $g \ln / \alpha$-ketoglutarate ( $g \ln / \alpha \mathrm{kg}$ ) ratios were measured in the same samples to determine whether these ratios were comparable and whether these metabolites could be used to predict patterns of $\mathrm{N}$ utilization and metabolism. GS activity was measured using the transferase assay, as well as the forward reaction assay, to determine the in vivo potential for $\mathrm{NH}_{4}{ }^{+}$assimilation relative to the diel pattern of $\mathrm{N}_{2}$ fixation. By characterizing the cellular biochemical and physiological conditions under which $\mathrm{N}_{2}$ fixation and $N$ uptake occur, we hoped to identify factors contributing to the control and regulation of these processes in Trichodesmium spp.

\section{METHODS}

Sample collection. Concentrations of intracellular metabolite pools of glu, gln and $\alpha$-ketoglutarate and rates of $\mathrm{N}_{2}$ fixation, $\mathrm{N}$ uptake, and GS activity were measured in natural assemblages of Trichodesmium spp. from the tropical North Atlantic Ocean during cruises aboard the RV 'Gyre' in May 1994 and the RV 'Seward Johnson' in April 1996, and the Eastern Caribbean Sea during cruises aboard the RV 'Seward Johnson' in January 1995 and October 1996. The same parameters were measured in Trichodesmium IMS101 isolated from coastal North Carolina and grown on an N-depleted seawater medium (Prufert-Bebout et al. 1993). Colonies of Trichodesmium spp. were collected in the field using a $202 \mu \mathrm{m}$ mesh plankton net towed at $<1$ knot for 10 to $15 \mathrm{~min}$ at depths $<30 \mathrm{~m}$ (unless otherwise specified). The ship was stopped during the deployment and recovery of the net. After dilution of the cod end sample with filtered seawater, colonies were transferred into GF/F filtered seawater using inoculating loops. GF/F filters have a nominal pore size of 0.7 to $0.8 \mu \mathrm{m}$. Bacterial-size cells pass through these filters and were likely present in the seawater.

Culture conditions. Cultures of Trichodesmium IMS101 were grown in an enriched seawater medium depleted in combined $\mathrm{N}$ as described by PrufertBebout et al. (1993). Cultures were maintained in incubators at $28^{\circ} \mathrm{C}$ on a $14: 10 \mathrm{~h}$ light:dark schedule at the 
Chesapeake Biological Laboratory (CBL). Light levels in the incubators were about 55 to $65 \mu \mathrm{mol}$ quanta $\mathrm{m}^{-2}$ $s^{-1}$ PAR supplied by banks of cool white fluorescent lighting. Cells were transferred using sterile techniques under a laminar flow hood and maintained in exponential growth to prevent excess bacterial accumulation. Non-Trichodesmium bacterial abundance in cultures was estimated as $<1 \%$ of the total cell numbers based on microscopic examinations. Bacteria were not observed in the culture medium. Cultures were swirled daily in order to prevent cells and filaments from adhering to the sides of the culture vessels. Prior to each sampling, cultures were swirled to ensure homogenous sampling.

Nitrogenase activity. Rates of $\mathrm{N}_{2}$ fixation were measured by the acetylene reduction method as described by Capone (1993). Ethylene production from acetylene was measured using a Shimadzu mini-Il flame ionization gas chromatograph having a 2 m Porapak $\mathrm{R}$ column and quantified against an ethylene gas standard. Ten colonies were counted into $14 \mathrm{ml}$ serum vials containing $10 \mathrm{ml}$ of $\mathrm{GF} / \mathrm{F}$ filtered seawater leaving $4 \mathrm{ml}$ of headspace. Care was taken to select colonies of similar size and to approximate a uniform biomass among vials. Vials without added Trichodesmium colonies were prepared in parallel with some of the incubations to correct for background $\mathrm{N}_{2}$ fixation in the filtered seawater. Vials were sealed and $1 \mathrm{ml}$ of acetylene (>99.9\%) was added to the headspace. A time-zero gas sample was extracted and the vials were placed in incubators on deck and supplied with a steady flow of seawater under neutral density screening to simulate mixing, temperature and light conditions in the upper water column. The duration of incubations for $\mathrm{N}_{2}$ fixation ranged from several to $12 \mathrm{~h}$. Measurements of ethylene production were made by removing $100 \mu l$ of headspace gas from each vial immediately after, and at intervals of every 1 to $2 \mathrm{~h}$ after, the addition of acetylene. Ethylene production in the sample vials was estimated relative to a $\mathrm{C}_{2} \mathrm{H}_{4}$ standard gas. Estimates of $\mathrm{N}_{2}$ fixation rates were calculated using the equations of Capone (1993) using a conversion factor of 4. $\mathrm{N}_{2}$ fixation rates were normalized per colony for natural populations.

Because cultured populations did not form colonies. rates of acetylene reduction in Trichodesmium IMS101 were measured by withdrawing $10 \mathrm{ml}$ of a well-mixed parent culture and placing it into the serum vial. Vials were sealed and $1 \mathrm{ml}$ of acetylene was introduced into the headspace. $N_{2}$ fixation rates were normalized to particulate $\mathrm{N}$ concentration in cultures. Control. assays were conducted on $10 \mathrm{ml}$ of the seawater medium to determine whether there was any acetylene reduction associated with the seawater medium. No activity was found. Replicate injections of sample and $\mathrm{C}_{2} \mathrm{H}_{4}$ standard gas were reproducible to within about $1 \%$.
${ }^{15} \mathrm{~N}$ uptake. Rates of $\mathrm{N}$ uptake were measured using ${ }^{15} \mathrm{~N}$ tracer techniques as outlined in Glibert \& Capone (1993), using highly (>98\%) enriched ${ }^{15} \mathrm{~N}$ substrates For field studies, colonies previously picked into GF/F filtered seawater were counted into polycarbonate incubation bottles containing 50 or $100 \mathrm{ml} \mathrm{GF} / F$ filtered, low-nutrient seawater (20 colonies per incubation). Uptake experiments were initiated by adding a ${ }^{15} \mathrm{~N}$ substrate $\left(\mathrm{NH}_{4}{ }^{*}, \mathrm{NO}_{3}{ }^{-}\right.$, urea, glu or a commercial $\operatorname{mix}$ of $A A$ ).

Because nutrients in the surface waters of the study sites were typically at the limit of analytical detection $(0.03 \mu \mathrm{M})$, additions of $0.03 \mu \mathrm{M}{ }^{15} \mathrm{~N}^{-1}$ were used These additions represented enrichments of ambient concentrations and may have stimulated uptake. The duration of incubations was 1 or 2 h except when specifically noted. ${ }^{15} \mathrm{~N}$ incubations were terminated by gently filtering $(<125 \mathrm{~mm} \mathrm{Hg})$ the contents of the incubation bottles onto pre-combusted $\left(450^{\circ} \mathrm{C}\right.$ for 2 to $4 \mathrm{~h}$ ) $\mathrm{GF} / \mathrm{F}$ filters. Filters were rinsed 3 times with low $\mathrm{N}$ filtered seawater to remove any tracer that was not taken up by cells. Time-zero controls were filtered immediately after the ${ }^{15} \mathrm{~N}$ addition and the concentration of ${ }^{15} \mathrm{~N}$ was measured to correct for ${ }^{15} \mathrm{~N}$ label adsorption to the filters. Samples were frozen and returned to the CBL for analysis.

The effect of substrate concentration on uptake rates was estimated for the different $\mathrm{N}$ compounds. Concentrations of $0.03,0.3,3.0$, and $30 \mu \mathrm{M}^{15} \mathrm{~N} \mathrm{NH}_{4}{ }^{+}, \mathrm{NO}_{3}{ }^{-}$, urea, glu and AA were added to $100 \mathrm{ml}$ incubation botthes containing 20 colonies of Trichodesmium spp. and incubated for $2 \mathrm{~h}$ in the morning, as described above. The uptake velocities calculated from measurements of ${ }^{15} \mathrm{~N}$ uptake were plotted by using Lineweaver-Burk transformations ( $S / v$ vs $S$, where $S$ is the substrate concentration in $\mu \mathrm{M}$ and $v$ is velocity $\mathrm{h}^{-1}$ ) to estimate the half saturation constant $\left(K_{\mathrm{s}}\right)$ for each $N$ source. Because $S$ included some unknown substrate concentration less than the analytical detection limit for that nutrient $\left(S_{n}\right)$ we expressed the half saturation constant as $K_{\mathrm{s}}+S_{\mathrm{n}}$

To measure ${ }^{15} \mathrm{~N}$ uptake in cultures of Trichodesmium IMS101, $20 \mathrm{ml}$ of a well-mixed parent culture was transferred into an acid-cleaned $24 \mathrm{ml}$ scintillation vial and inoculated with $0.03 \mu \mathrm{M}$ of either ${ }^{15} \mathrm{NH}_{4}{ }^{+}$or ${ }^{15} \mathrm{~N}$ enriched glu. Vials were returned to the culture incubator for $1 \mathrm{~h}$ and samples collected onto pre-combusted GF/F filters and rinsed 3 times with the $\mathrm{N}$-depleted seawater medium as for field samples. Filters were frozen until analyzed.

Sample ${ }^{15} \mathrm{~N}$ enrichment and total particulate nitrogen mass were measured by mass spectrometry on a Europa Scientific ANCA-SL 20-20 IRMS (Isotope Ratio Mass Spectrometer against a peptone standard. The instrument was calibrated and tuned before each sample run. A full reference sample set (6 samples) was 
analyzed at the beginning and end of each set of 25 samples. Two reference samples were inserted after every 5th sample throughout the sample run to verify instrument performance over the course of sample runs. Reference samples were reproducible to within 0.0001 atom $\%$.

GS activity. In field studies, 20 to 100 colonies of Trichodesmium spp. were rinsed and then counted into incubation bottles containing fresh GF/F filtered seawater. The contents of these bottles were then filtered onto polycarbonate filters ( 3.0 to $8.0 \mu \mathrm{m}$ pore size). Filters were flash frozen in liquid $\mathrm{N}_{2}$ and stored at $-80^{\circ} \mathrm{C}$ until analyzed. In culture studies with Trichodesmium IMS101, the parent culture was gently mixed and a known culture volume was gently filtered onto polycarbonate filters, frozen and stored in liquid $\mathrm{N}_{2}$ until analyzed.

GS activity was measured on crude cell extracts either immediately or after storage in liquid $\mathrm{N}_{2}$ for $<2$ wk. GS biosynthetic and transferase activities were measured using the $\gamma$-glutamyltransferase and $\gamma$-glutamylsynthetase assays of Stadtman et al. (1979) with the modifications described in Lee et al. (1988) after extraction in HEPES buffer solution. The GS transferase assay measures the amount of $\gamma$-glutamylhydroxamate produced in the following reaction catalyzed by GS:

$$
\begin{aligned}
\mathrm{gln}+\mathrm{ADP}+\mathrm{NH}_{2} \mathrm{OH} \frac{\mathrm{AsO}_{4}}{\mathrm{Mn}^{*}\left(\mathrm{Mg}^{*+1}\right.} \\
\text { y-glutamylhydroxamate }+\mathrm{NH}_{3}
\end{aligned}
$$

This reaction does not occur in vivo but the $\gamma$-glutamylhydroxamate produced can be measured spectrophotometrically and the reaction is analogous to the reverse of the in vivo biosynthetic reaction:

$$
\mathrm{glu}+\mathrm{NH}_{3}+\mathrm{ATP} \longrightarrow \mathrm{gln}+\mathrm{ADP}+\mathrm{P}_{\mathrm{i}}
$$

When $\mathrm{Mn}^{++}$is present as the divalent cation in the assay, the activity of both modified and unmodified enzyme is stimulated. The cation $\mathrm{Mg}^{++}$has been shown to inhibit the activity of modified enzyme in other species (Lee et al. 1988)

The GS biosynthetic assay measures the production of $\gamma$-glutamylhydroxamate from the forward GS reaction as follows:

$$
\begin{aligned}
\text { glu }+\mathrm{ATP}+ & \mathrm{NH}_{2} \mathrm{OH} \longrightarrow \\
& \gamma \text {-glutamylhydroxamate }+\mathrm{ADP}+\mathrm{P}_{\mathrm{i}}
\end{aligned}
$$

This assay provides an estimate of the in vivo potential for gln synthesis via GS. It has the analytical advantage over 'true' biosynthetic assays of having a stable end product that is easily measured (Slawyk \& Rodier 1988). In these studies we measured both GS transferase activity, in the presence of $\mathrm{Mn}^{++}$, and GS biosynthetic activity, in the presence of $\mathrm{Mg}^{++}$, and calculated the ratio between the 2 activities. Changes in the ratio might be indicative of enzyme modification and the proportion of available enzyme that is biosynthetically active (Lee et al. 1988).

The HEPES extraction buffer and the reaction 'stop' mix were prepared fresh daily. Reaction mixtures were prepared fresh just prior to initiating assays and warmed to the assay temperature just prior to use. Transferase and biosynthetic assays were each set up in triplicate for each sample. Assays were initiated by adding cell homogenate to tubes containing the warmed reaction mixture and the reaction proceeded in a water bath or a heating block maintained at $30^{\circ} \mathrm{C}$. Background absorption was corrected for by stopping the reaction in 1 of the 3 replicate assay tubes immediately after addition of the crude cell extract. Reaction times were optimized for both the GS transferase and GS biosynthetic assays by measuring activity over several time courses using cell extract from freshly harvested Trichodesmium spp. Reaction times were selected from the portion of the curve in which enzyme activity increased linearly over time, $10 \mathrm{~min}$ for transferase assay and $15 \mathrm{~min}$ for the biosynthetic assay. The reaction mixtures were adjusted to $\mathrm{pH} 7.7$ (transferase) and 7.5 (biosynthetic) using $10 \mathrm{~N} \mathrm{NaOH}$ prior to initiating the assays (Meeks pers. comm.).

The $\gamma$-giutamylhydroxamate produced from the biosynthetic and transferase reactions was measured using a Shimadzu UV-160 spectrophotometer and the concentration determined relative to the standard curve associated with each sample set. Replicate measurements varied by less than 0.010 absorption units for transferase assays and 0.001 absorption units for biosynthetic assays (usually $<1 \%$ ). Very little error was associated with the replicate assays. All standard curves had regression coefficients of $\mathrm{R}^{2}>0.99$.

Protein analysis. Total cell protein was measured spectrophotometrically using the Lowry procedure on a TCA precipitate of the cell extracts used for the GS assays (Sigma Protein Assay Kit No. P5656). Absorbance was measured on a Shimadzu UV-160 spectrophotometer. Protein content was estimated in replicate assays against a standard curve of bovine serum albumin (BSA) $\left(\mathrm{R}^{2}>0.99\right)$. Estimates of protein content in replicate analyses of the same sample extract varied by $<2 \%$. Specific GS activity was calculated and rates of enzyme activity expressed as the nmoles of $\gamma$-glutamylhydroxamate produced per $\mu \mathrm{g}$ protein or per ml culture per hour.

Amino acid analysis. Samples for the analysis of intracellular AA pools were collected in the same manner as those designated for the GS assays. Samples collected in the field studies were immediately frozen and stored in liquid $\mathrm{N}_{2}$ for the duration of the cruises and transported to the CBL on dry ice. They were stored at $-80^{\circ} \mathrm{C}$ in the Iaboratory until analysis. Samples col- 
lected during culture studies in the laboratory were frozen and stored in liquid $\mathrm{N}_{2}$ until analysis. Intracellular pools were extracted in $0.3 \mathrm{~N}$ perchloric acid. The extract was neutralized and chloride precipitated with $2 \mathrm{M}$ potassium carbonate as described by Senior (1975). AA were analyzed by OPA fluorescence using reverse-phase high performance liquid chromatography (HPLC) as described by Flynn (1988) and Cowie \& Hedges (1992). Analyses were performed on a Waters system with a refrigerated autosampler and fitted with a Novapac column $(150 \times 3.9 \mathrm{~mm}, 4 \mu \mathrm{m}, \mathrm{C}-18$ packing $)$. The mobile phase, supplied at a rate of $1.5 \mathrm{ml} \mathrm{min}^{-1}$, was a gradient (solvent $\mathrm{A}: 0.025 \mathrm{M}$ sodium acetate, $2 \%$ tetrahydrofuran, $0.05 \% \mathrm{Brij}_{\text {; }}$ solvent B: $100 \%$ methanol). AA were resolved by modifying the gradient and $\mathrm{pH}$ of solvent $\mathrm{A}$ to achieve optimum separation. Individual AA peaks were identified by comparison with retention times from mixtures of pure AA standards. AA were quantified relative to a standard AA mix (Sigma A-2161) to which gln had been added. Standards were run after every 5 samples. Distilled water blanks were run with each sample set and subtracted from the sample measurement. Neutralized perchloric acid extraction blanks were run with each group of samples extracted. Reproducibility of measurements to within $1 \%$ was established by repeat injections. Standard curves were run at the beginning and end of each sample set $\left(\mathrm{R}^{2}>0.99\right)$. Only the glu and gln concentrations are reported here. $\alpha \mathrm{kg}$ was measured enzymatically as described by Lowry et al. (1971) and Lowry \& Passonneau (1972).

Inorganic nutrient analysis. Intracellular $\mathrm{NH}_{4}{ }^{+}$concentrations were measured on a number of occasions by rupturing cells with a combination of heat and osmotic shock (Thoresen et al. 1982). Interfilamental nutrient concentrations were approximated by placing 30 colonies into $30 \mathrm{ml}$ nutrient-free filtered seawater, gently agitating them to disperse trichomes without disrupting cells, and then collecting the resultant filtrate for nutrient analysis, as described in Capone et al. (1994). Samples for measuring the ambient nutrient and dissolved free amino acid (DFAA) concentrations in the GF/F filtrate used in each study were collected and measured immediately or stored frozen $\left(-20^{\circ} \mathrm{C}\right)$ until analysis. Nutrients $\left(\mathrm{NH}_{4}{ }^{+}, \mathrm{NO}_{3}{ }^{-}\right.$, urea) were measured colorimetrically using a Technicon autoanalyzer II (Friederich \& Whitledge 1972) equipped with an Alpchem autosampler and FASPac software. DFAA were measured by HPLC as described above. Concentrations were determined by comparison with standard curves $\left(R^{2}>0.99\right)$. Repeat measurements were made from the same sample to verify reproducibility of measurements to within about $2 \%$.

Field measurements were normalized per colony and culture measurements were normalized per unit
N. An average colony was estimated to be 0.1 to $0.2 \mu \mathrm{g}$ $N$ (Carpenter 1983a, Mulholland unpubl. results) although this level varied with colony size. Cultures ranged from 0.7 to $1.0 \mu \mathrm{g} \mathrm{N} \mathrm{ml}^{-1}$. $\mathrm{N}$ uptake measurements were expressed in units of reciprocal time to avoid the problems of variable colony size and variations in total biomass among incubations and to allow better comparisons with uptake rates measured previously and uptake rates measured in cultures in which colonies did not form.

Because the analytical error associated with the measurement of AA, GS activity, $\mathrm{N}_{2}$ fixation by acetylene reduction and ${ }^{15} \mathrm{~N}$ uptake were negligible based on instrument performance and reproducibility between replicate assays, only that error associated with differences between replicate samples is presented in the results. Replicate measurements of acetylene reduction and ${ }^{15} \mathrm{~N}$ uptake were made for most studies and errors are presented as standard deviations among sample replicates. Due to biomass limitation in both natural and cultured populations and the handling time necessary for sample collection and preparation, replication was not possible in some of these experiments.

\section{RESULTS}

\section{Natural populations}

$\mathrm{N}_{2}$ fixation and $\mathrm{N}$ uptake

Rates of $\mathrm{N}_{2}$ fixation, as estimated by acetylene reduction, by Trichodesmium spp. varied among sampling stations and sampling dates. The highest $\mathrm{N}$ turnover rates attributed to $\mathrm{N}_{2}$ fixation, up to $0.4 \% \mathrm{~h}^{-1}$. (equal to $0.6 \mathrm{nmol} \mathrm{N}$ colony ${ }^{-1} \mathrm{~h}^{-1}$ ) were recorded at mid-day (Table 1). The daily pattern of nitrogenase activity for individual incubations and Trichodesmium spp. populations was a bell-shaped curve centered around mid-day as shown in previous studies (Table 1, Capone et al. 1990, 1994). While analytical precision was high (see 'Methods'), replicate incubations could vary by up to $50 \%$. This is consistent with variability found in earlier studies (Carpenter \& McCarthy 1975, Carpenter \& Price 1977. Capone 1990, 1994). Activity decreased over the course of the afternoon and was absent by evening. $N_{2}$ fixation was not detected at night.

$\mathrm{N}$ uptake $\left(\mathrm{NH}_{4}{ }^{+}, \mathrm{NO}_{3}{ }^{-}\right.$, urea, glu and a mixed $\mathrm{AA}$ substrate) was detected in Trichodesmium spp. collected from low nutrient areas of the North Atlantic Ocean and the Eastern Caribbean Sea and N uptake rates varied among populations, between sample replicates, and relative to calculated rates of $\mathrm{N}_{2}$ fixa- 
Table 1. Summary of measured rates of $\mathrm{N}$ uptake $\left(\% \mathrm{~N} \mathrm{~h}^{-1}\right)$ and $\mathrm{N}_{2}$ fixation $\left(\% \mathrm{~N} \mathrm{~h}^{-1}\right)$ in Trichodesmium spp., by date. All samples were collectrd from the tropical and subtropical Northwest Atlantic Ocean. Tracer additions of ${ }^{15} \mathrm{~N}$ substrates were $0.03 \mu \mathrm{M}$. Ambient concentrations of $\mathrm{NH}_{4}{ }^{+}, \mathrm{NO}_{3}{ }^{-}$, and urea were at or below the limits of detection $(0.03 \mu \mathrm{M})$ and ambient glutamate (Glu) and amino acid (A.A) concentrations were $<10$ and $<100 \mathrm{nM}$, respectively. The average colony had $0.1 \mu g$ at $\mathrm{N}$ colony $^{-1}$. Standard deviations are reported in parentheses. ND: no $\mathrm{N}$ uptake or $\mathrm{N}_{2}$ fixation was detected. NR: no replicate samples

\begin{tabular}{|c|c|c|c|c|c|c|c|}
\hline $\begin{array}{l}\text { Date } \\
(\mathrm{d} / \mathrm{mo} / \mathrm{yr})\end{array}$ & $\begin{array}{l}\text { Time } \\
\text { (h) }\end{array}$ & $\begin{array}{c}\mathrm{N}_{2} \\
\text { fixation } \\
\left(\% \mathrm{~h}^{-1}\right)\end{array}$ & $\begin{array}{c}\mathrm{NH}_{4}{ }^{+} \\
\text {uptake } \\
\left(\% \mathrm{~h}^{-1}\right)\end{array}$ & $\begin{array}{c}\mathrm{NO}_{3}^{-} \\
\text {uptake } \\
\left(\% \mathrm{~h}^{-2}\right)\end{array}$ & $\begin{array}{l}\text { Urea } \\
\text { uptake } \\
\left(\% \mathrm{~h}^{-1}\right)\end{array}$ & $\begin{array}{c}\text { Glu } \\
\text { uptake } \\
\left(\% \mathrm{~h}^{-1}\right)\end{array}$ & $\begin{array}{c}\text { AA } \\
\text { uptake } \\
\left(\% \mathrm{~h}^{-1}\right)\end{array}$ \\
\hline $12 / 06 / 94$ & 04:00 & ND & & & $0.09(0.08)$ & & \\
\hline $20 / 10 / 96$ & $07: 00$ & $0.01(0.002)$ & $0.067(N R)$ & $0.0043(\mathrm{NR})$ & $0.03(\mathrm{NR})$ & $0.09(\mathrm{NR})$ & \\
\hline $12 / 06 / 94$ & $09: 48$ & $0.23(0.04)$ & $0.27(0.07)$ & & $0.03(0.01)$ & & \\
\hline $17 / 10 / 96$ & $10: 45$ & & $0.07(\mathrm{NR})$ & & ND & & \\
\hline $27 / 10 / 96$ & $11: 10$ & $0.34(0.10)$ & $0.06(0.001)$ & $0.0003(0.0003)$ & $0.002(0.003)$ & $0.015(0.001)$ & $0.011(0.002)$ \\
\hline $19 / 10 / 96$ & $11: 15$ & & $0.44(0.27)$ & ND & $0.04(0.006)$ & $0.012(0.006)$ & \\
\hline $16 / 10 / 96$ & $13: 45$ & $0.40(0.03)$ & $0.70(0.28)$ & & & $0.37(0.40)$ & 0.32 (NR) \\
\hline $13 / 04 / 96$ & $14: 06$ & & $0.58(0.43)$ & & & & \\
\hline $06 / 11 / 96$ & $15: 00$ & $0.023(0.002)$ & $1.84(0.96)$ & & & $0.04(0.02)$ & \\
\hline $19 / 04 / 96$ & $15: 10$ & $0.046(0.03)$ & $0.19(0.06)$ & & & & \\
\hline $12 / 06 / 94$ & $15: 23$ & & & & $0.11(0.04)$ & & \\
\hline $13 / 10 / 96$ & $16: 00$ & ND & $0.65(\mathrm{NR})$ & & & & \\
\hline $28 / 10 / 96$ & $18: 50$ & ND & $0.04(0.001)$ & $0.0004(0.0001)$ & $0.0007(0.0001)$ & $0.015(0.001)$ & $0.02(0.006)$ \\
\hline $19 / 04 / 96$ & $19: 52$ & ND & $0.08(0.03)$ & & & & \\
\hline $12 / 06 / 94$ & $21: 00$ & ND & & & $0.11(0.013)$ & & \\
\hline
\end{tabular}

tion. Rates of ${ }^{15} \mathrm{NH}_{4}{ }^{+}$uptake were generally higher than those measured for other $\mathrm{N}$ substrates. $\mathrm{NH}_{4}{ }^{+}$ uptake exceeded rates of $\mathrm{N}_{2}$ fixation throughout most of the day and proceeded during the night when there was no $\mathrm{N}_{2}$ fixation (Table 1). The highest $\mathrm{NH}_{4}{ }^{*}$ uptake rates, up to $1.8 \% \mathrm{~h}^{-1}$, were measured during the day. Because ambient concentrations of $\mathrm{NH}_{4}{ }^{+}$were at or below the limits of detection, rates of ${ }^{15} \mathrm{~N}$ uptake may have been stimulated by $0.03 \mu \mathrm{M}$ additions.

Rates of urea uptake were variable among studies and ranged from zero to about $0.11 \% \mathrm{~h}^{-1}$. Glu and mixed AA uptake rates were lower but always detected. Ambient concentrations of AA were $<30 \mathrm{nM}$. Rates of ${ }^{15} \mathrm{NO}_{3}{ }^{-}$uptake were low or undetectable.

On average a total of about $12 \%$ of the cell $\mathrm{N}$ was turned over during a $24 \mathrm{~h}$ period, and about $2.3 \%$ was attributed to $\mathrm{N}_{2}$ fixation. This constitutes a $\mathrm{N}$ based turnover time of about $8.5 \mathrm{~d}$. Based on a $10 \mathrm{~h}$ period of $\mathrm{N}_{2}$ fixation, a maximum of $4 \%$ of the total colony $\mathrm{N}$ biomass could be provided daily by this $\mathrm{N}$ utilization pathway. This would yield doubling times of about 25 to 40 d. $N$ turnover due to $N_{2}$ fixation may be lower (and the doubling time greater) when we allow that cells fix $\mathrm{N}_{2}$ at maximal rates only around mid-day.

Kinetic constants varied among stations and substrates. Trichodesmium spp. colonies had the highest capacity $\left(V_{\text {max }}\right.$ ) for $\mathrm{NH}_{4}{ }^{+}$uptake and the lowest capacity for $\mathrm{NO}_{3}{ }^{-}$uptake (Fig. 1). Uptake of $\mathrm{NO}_{3}{ }^{-}$was not detected at concentrations less than $3.0 \mu \mathrm{M}$ and so the low $K_{\mathrm{s}}$ values calculated may not reflect the actual affinity for this substrate. Relatively low $K_{\mathrm{s}}+S_{\mathrm{n}}$ and high $V_{\text {max }}$ values were calculated for $\mathrm{NH}_{4}{ }^{+}$, glu and AA uptake, indicating a high affinity for these $\mathrm{N}$ substrates (Fig. 1). Urea uptake was not saturated at $30 \mu \mathrm{M}$ and so $K_{\mathrm{s}}+S_{n}$ values may be underestimated in our calculations.

Urea and $\mathrm{NH}_{4}{ }^{+}$concentrations were measured in interfilamental spaces in some populations of Trichodesmium spp. by gentle disaggregation of colonies. Extracellular concentrations of $\mathrm{NH}_{4}{ }^{+}$and urea associated with colonies were generally elevated relative to ambient water column concentrations (Table 2). Interfilamental concentrations of $\mathrm{NH}_{4}{ }^{+}$were as high as $211 \mu \mathrm{M}$ while urea concentrations of up to $315 \mu \mathrm{M}$ were measured. Because cells have a high uptake capacity and affinity for these $2 \mathrm{~N}$ substrates and since there are also high nutrient concentrations in the area around the cells, uptake of these compounds may be important in natural systems.

\section{Intracellular metābolite pools}

Intracellular $\alpha \mathrm{kg}$ concentrations were highest early in the morning and declined in the afternoon (Fig. 2A,B). Although replicate assays varied by $<1 \%$, variation among samples collected at the same time varied more. Increases in gln concentrations generally increased in parallel with rates of $\mathrm{N}_{2}$ fixation (Fig. 2C,D). Concentrations of gin (usually $<1 \mathrm{nmol}$ 


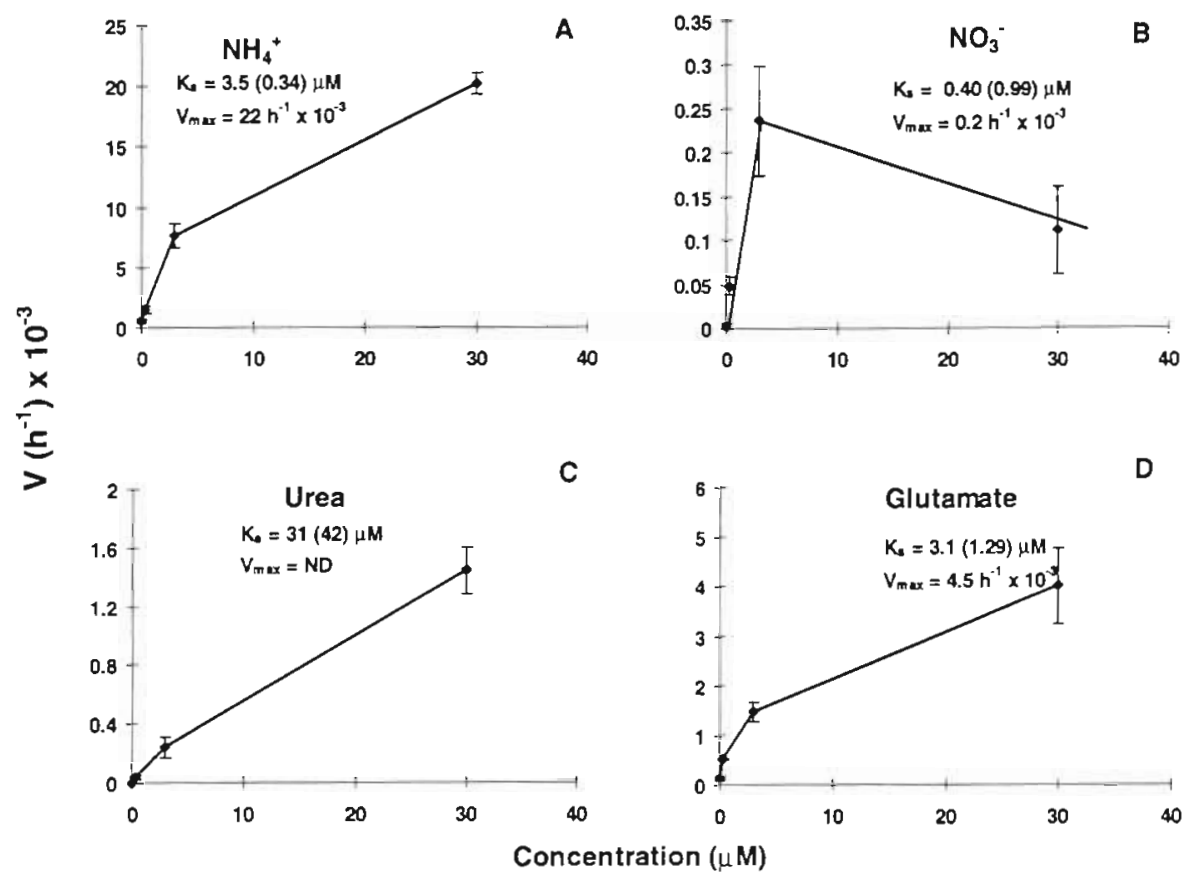

Fig. 1. Saturation curves for combined $\mathrm{N}$ sources: (A) $\mathrm{NH}_{4}{ }^{+}$, (B) $\mathrm{NO}_{3}{ }^{-}$, (C) urea, and (D) glutamate in natural populations of Trichodesmium spp. from the tropical North Atlantic Ocean. Value for $K_{\mathrm{s}}+S_{\mathrm{n}}$ (standard deviation) and $V_{\max }$ indicated in each panel. All incubations were done during the morning after sunrise. ND: value could not be determined

colony $^{-1}$ ) were always lower than concentrations of glu $\left(<5\right.$ nmol colony ${ }^{-1}$ ). As previously reported (Capone et al. 1994), the peak in intracellular glu concentrations was slightly later in the day than that for gln (Fig. 2C,D). There was an apparent diel pattern in metabolite ratios in Trichodesmium spp. The gln/ $\alpha \mathrm{kg}$ was highest before or at mid-day and lowest during the night (Fig. 2E,F). The ratio ranged from about 0.2 to 2 . The highest gln/glu ratios were measured before or about mid-day (range 0.1 to 0.6) (Fig. 2G,H).

Intracellular $\mathrm{NH}_{4}{ }^{+}$pools ranged from 209 to $1822 \mu \mathrm{M}$ (Table 3), similar to the ranges of values reported for glu and gin.

Table 2. Concentrations of nutrients in interfilamental areas of Trichodesmium spp. colonies from the North Atlantic Ocean. Calculations were based on an average colony size of 5 by $0.5 \mathrm{~mm}$. Ten percent of the total cylindrical volume was interfilamental spaces (Capone et al. 1994). Standard deviations from 3 replicate analyses are reported in parentheses. ND: nutrient was not detected. The detection limit was $0.03 \mu \mathrm{M}$

\begin{tabular}{|lcccc}
$\begin{array}{l}\text { Date } \\
(\mathrm{d} / \mathrm{mo} / \mathrm{yr})\end{array}$ & \multicolumn{2}{c}{$\mathrm{NH}_{4}{ }^{+}$conc. $(\mu \mathrm{M})$} & \multicolumn{2}{c}{ Urea conc. $(\mu \mathrm{M})$} \\
& Ambient & Interfilamental & Ambient Interfilamental \\
\hline $31 / 05 / 94$ & $\mathrm{ND}$ & $\mathrm{ND}$ & $\mathrm{ND}$ & $182(4.9)$ \\
$06 / 06 / 94$ & $\mathrm{ND}$ & $211(2.5)$ & ND & $315(9.9)$
\end{tabular}

Intracellular pools of glu and gln and the ratio between these pools varied depending on the depth from which Trichodesmium colonies were collected. The glu and gln concentrations were highest in colonies collected from just below the surface $(5 \mathrm{~m})$ and then decreased with depth (Fig. 3A). The gln/glu ratio was highest at the surface and decreased with depth (Fig. 3B). The highest gln/glu and gln/akg ratios measured were about 0.7 and 7 , respectively, in samples collected from near surface waters. The ratios rapidly decreased to between 0.2 and 0.4 for gln/glu and $<2$ for the $g \ln / \alpha \mathrm{kg}$ for samples collected deeper in the euphotic zone (Fig. 3C).

In experiments in which Trichodesmium spp. colonies were collected from $15 \mathrm{~m}$ and then incubated on deck at various simulated light levels, there were no consistent patterns in intracellular glu and gln concentrations with respect to light level (data not shown). Intracellular pools of $\alpha \mathrm{kg}$ were lowest at the higher light levels and, therefore, the gln/ $\alpha \mathrm{kg}$ ratio was slightly higher in the high light treatment but did not change much compared to the lower light treatments.

\section{GS activity}

GS transferase activity was, on average, between 8 and $16 \mathrm{nmol} \gamma$-glutamylhydroxamate $\mu g^{-1}$ protein $\mathrm{h}^{-1}$, more than 20 times higher than GS biosynthetic activ- 

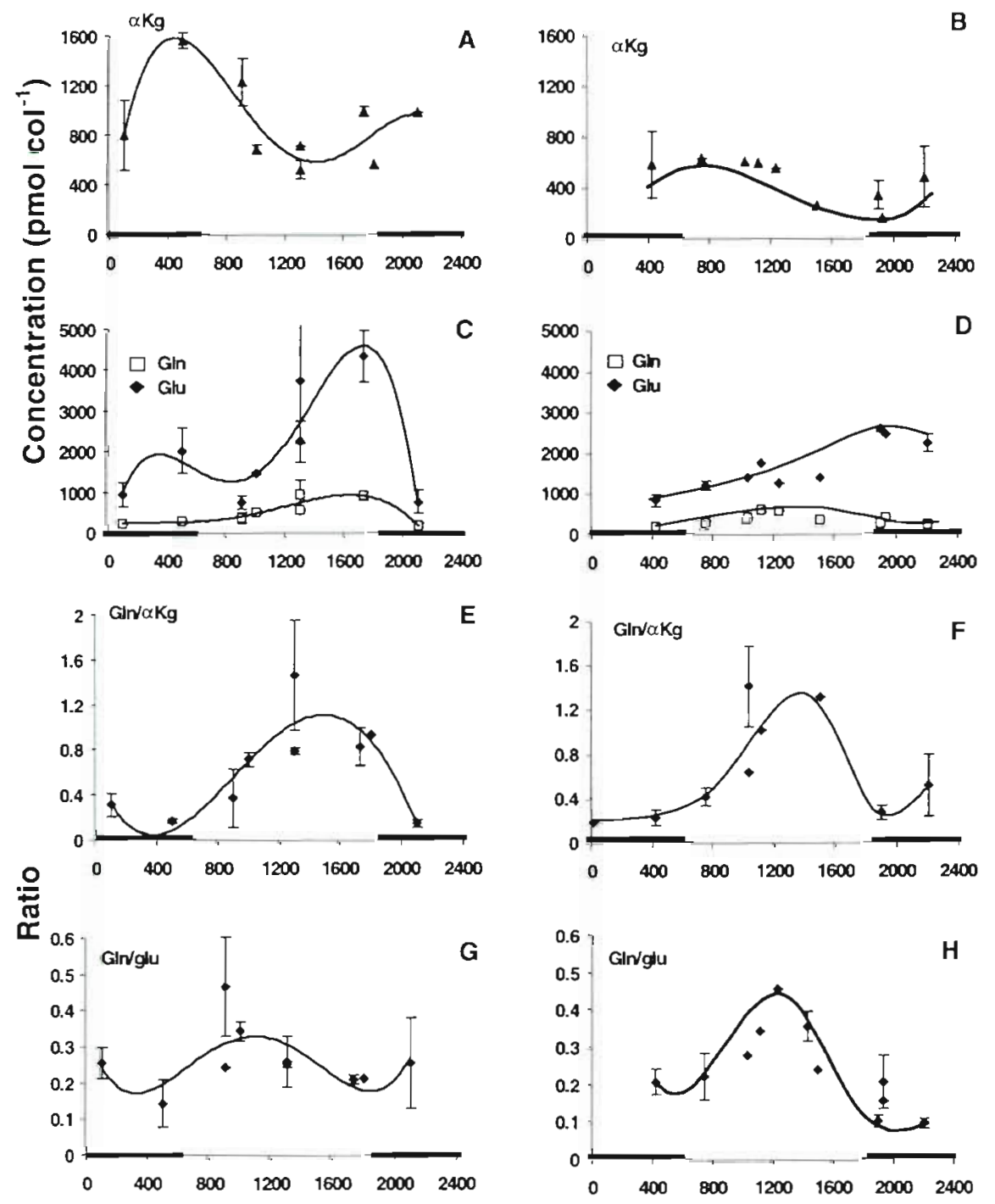

Time (h)

Fig. 2. Intracellular concentrations of $(A, B) \alpha$-ketoglutarate, (C,D) glutamate and glutamine; intracellular ratios of $(E, F)$ gln/ $\alpha k g$ and $(G, H)$ gln/glu in natural populations of Trichodesmium spp. (tufts) from $(A, C, E, G)$ the tropical North Atlantic Ocean and $(B, D, F, H)$ the Caribbean Sea Error bars are standard deviations calculated from 3 Trichodesmium spp. samples. Bars on the $x$-axis indicate the dark period. Curves were drawn in Excel ${ }^{k}$ using a 4 th order polynomial regression

\begin{tabular}{|c|c|c|c|c|}
\hline $\begin{array}{l}\text { Date } \\
\text { (d/mo/yr) }\end{array}$ & $\begin{array}{l}\text { Colony } \\
\text { form }\end{array}$ & Time & $\begin{array}{l}\mathrm{NH}_{4}^{+} \\
\text {conc. } \\
\left.\text { (nmol colony }{ }^{-1}\right)\end{array}$ & $\begin{array}{l}\mathrm{NH}_{4}^{+} \\
\text {Conc. } \\
(\mu \mathrm{M})\end{array}$ \\
\hline \multicolumn{2}{|c|}{$31 / 05 / 94$ Tufts and puffs } & 1000 & 0.58 & 209 \\
\hline $05 / 06 / 94^{\mathrm{d}}$ & Tufts & 1000 & 1.47 & 868 \\
\hline $05 / 06 / 94^{\mathrm{d}}$ & Puffs & 1000 & 2.67 & 494 \\
\hline $28 / 05 / 94$ & ts and puffs & 1330 & 0.83 & 301 \\
\hline $06 / 06 / 94^{d}$ & Tufts & 1330 & 0.77 & 4.54 \\
\hline $06 / 06 / 94^{\circ}$ & Puffs & 1339 & 0.57 & 1050 \\
\hline $31 / 05 / 94$ & Tufts & 1500 & 3.42 & 809 \\
\hline $31 / 05 / 94$ & Puffs & 1500 & 2.46 & 1820 \\
\hline \multicolumn{5}{|c|}{$\begin{array}{l}\text { On these days the average colony size was estimated to } \\
\text { be about } 100 \text { trichomes colony }{ }^{-1} \text {. On the other days, the } \\
\text { average colony was comprised of about } 250 \text { trichomes }\end{array}$} \\
\hline
\end{tabular}

Table 3. Intracellular $\mathrm{NH}_{4}{ }^{+}$pools in Trichodesmium spp collected from the tropical North Atlantic Ocean. All measurements are reported. Replicate samples were not collected on these days. Tufts represent fusiform bundles of trichomes and puffs are a radial arrangement of trichomes. Intracellular concentrations were calculated based on an average of 100 cells trichome ${ }^{-1}$ (Marumo 1975, McCarthy \& Carpenter 1979 ) and cell volumes of $540 \mu \mathrm{m}^{3}$ for spherical colonies (puffs) and $1690 \mathrm{\mu m}^{3}$ for fusiform colonies (tufts) (Carpenter 1983a) 


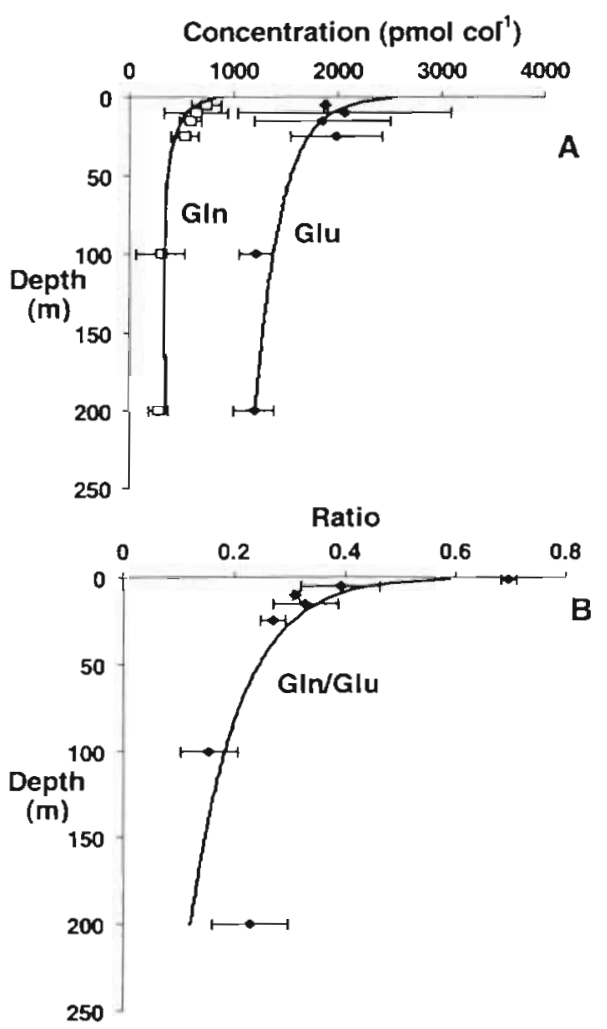

A

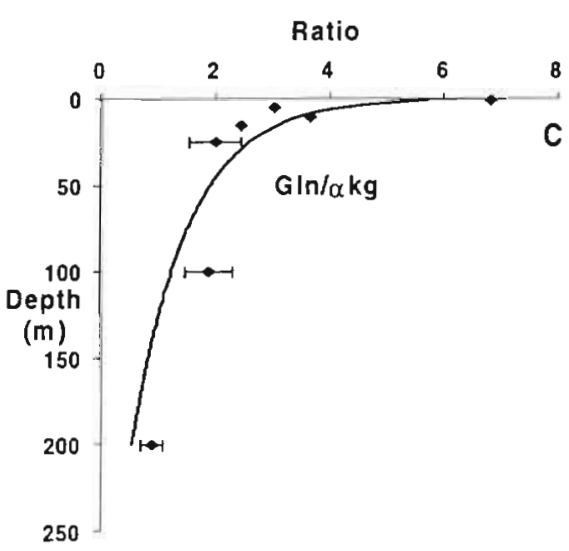

Fig. 3. Intracellular (A) glu and gln concentrations, (B) gln/glu ratios, and (C) gln/okg ratios in Trichodesmium spp. collected at a single station from different depths on the same day in the Caribbean Sea

ity (4 to $6 \mathrm{nmol} \gamma$-glutamylhydroxamate $\mu \mathrm{g}^{-1}$ protein $\mathrm{h}^{-1}$ ). Levels of activity were highest after mid-day and lower during the early morning. The ratio between GS transferase and GS biosynthetic activity varied only slightly during the course of the day, averaging between about 18 and 25 . There was a slight increase in the transferase/biosynthetic ratio in the afternoon but there was no significant trend. Few measurements were made during the dark period. As a result, discerning diel changes in activity is difficult.

\section{Cultured populations}

Biomass

The average $\mathrm{N}$ biomass of cultures of Trichodesmium IMS101 used in these experiments was $121 \mu \mathrm{Mol} \mathrm{N} \mathrm{l}^{-1}$. At this density, cells were in exponential phase growth.

\section{$\mathrm{N}_{2}$ fixation}

Assays for $\mathrm{N}_{2}$ fixation were initiated at 4 points during the light period and twice during the dark and monitored over time. In cultures of Trichodesmium IMS101, the highest average rates of $\mathrm{N}_{2}$ fixation $\left(1.05 \% \mathrm{~h}^{-1}\right)$ were measured during the middle of the light period (Table 4). These rates exceeded the rates of $\mathrm{N}_{2}$ fixation measured in natural populations of Trichodesmium spp. colonies. Activity increased after the onset of the light period and decreased during the latter half of the light period (Table 4). $\mathrm{N}_{2}$ fixation was not detected during the dark period. Integrating over the day and assuming maximal rates of $\mathrm{N}_{2}$ fixation throughout the $10 \mathrm{~h}$ light period, we estimate that there was a turnover of $11 \%$ of the cell $N$ per day due to $\mathrm{N}_{2}$ fixation. This translates to an $\mathrm{N}_{2}$ fixation-based $\mathrm{N}$ doubling time of about $9 \mathrm{~d}$.

\section{Nitrogen uptake}

Prior to the addition of Trichodesmium, $\mathrm{NH}_{4}{ }^{+}, \mathrm{glu}$ and gln were not measurable in the seawater medium. $\mathrm{NH}_{4}{ }^{+}$accumulated in the culture medium during growth of Trichodesmium IMS101, with concentrations ranging between 0.3 to $1.8 \mu \mathrm{M}$ over the diel cycle (Table 4). Additions of ${ }^{15} \mathrm{NH}_{4}{ }^{+}$were $<10 \%$ of the ambient $\mathrm{NH}_{4}{ }^{+}$concentration in the medium. Additions of ${ }^{15} \mathrm{~N}$-labeled glu represented $100 \%$ or more of ambient concentrations. Average rates of $\mathrm{NH}_{4}{ }^{+}$uptake were highest (average of $0.68 \% \mathrm{~h}^{-1}$ ) just after the onset of the light period and then were lower at mid-day $\left(0.2\right.$ to $\left.0.3 \% \mathrm{~h}^{-1}\right)$ when $\mathrm{N}_{2}$ fixation rates were high (Table 4). Uptake of $\mathrm{NH}_{4}{ }^{+}$represented about 20 to $40 \%$ of the $\mathrm{N}_{2}$ fixation rate at midday. Rates of $\mathrm{NH}_{4}{ }^{+}$uptake were greater than the rates of $\mathrm{N}_{2}$ fixation except around mid-day when $\mathrm{N}_{2}$ fixation rates were highest. In the afternoon, $\mathrm{NH}_{4}{ }^{+}$ uptake rates were lower than in the morning. Integrated over a day, $\mathrm{NH}_{4}{ }^{+}$uptake accounted for 10 to $16.3 \%$ of the total cell $N$ per day. There was a strong positive relationship $\left(\mathrm{R}^{2}=0.90\right)$ between the rate of $\mathrm{NH}_{4}{ }^{+}$uptake and the $\mathrm{NH}_{4}{ }^{+}$concentration measured in the culture medium (Fig. 4). 
Table 4. Summary of $\mathrm{N}$ uptake and $\mathrm{N}_{2}$ fixation rates by Trichodesmium IMS101 from experiments conducted on 12/06/96 using $0.03 \mu \mathrm{M}$ additions of ${ }^{15} \mathrm{NH}_{4}{ }^{-*}$ or ${ }^{1.5} \mathrm{~N}$-glutamate. Rates are expressed as turnover rates of $\%$ cell $\mathrm{N} \mathrm{h}^{-1}$. The standard deviations from 2 replicate incubations are reported in parentheses. ND: rates were not detected

\begin{tabular}{|cccccc|}
\hline $\begin{array}{l}\text { Time } \\
(\mathrm{h})\end{array}$ & $\begin{array}{c}\mathrm{N}_{2} \text { fixation } \\
\left(\% \mathrm{~h}^{-1}\right)\end{array}$ & $\begin{array}{c}\mathrm{NH}_{4}^{+} \\
\text {uptake } \\
\left(\% \mathrm{~h}^{-1}\right)\end{array}$ & $\begin{array}{c}\mathrm{NH}_{4}^{+} \\
\text {i.n medium } \\
(\mu \mathrm{M})\end{array}$ & $\begin{array}{c}\text { Glu } \\
\text { uptake } \\
\left(\% \mathrm{~h}^{-1}\right)\end{array}$ & $\begin{array}{c}\text { Glu } \\
\text { in medium } \\
\left(\mu \mathrm{M}^{+}\right)\end{array}$ \\
\hline $02: 39$ & $\mathrm{ND}$ & $0.559(0.19)$ & $0.11(0.04)$ & $0.03(0.002)$ & $0.004(0.001)$ \\
$07: 48$ & $0.0086(0.004)$ & $0.337(0.13)$ & $0.08(0.03)$ & $0.03(0.001)$ & $0.005(0.002)$ \\
$10: 20$ & $0.022(0.006)$ & $0.681(0.21)$ & $0.13(0.07)$ & $0.03(0.002)$ & $0.006(0.002)$ \\
$13: 38$ & $1.046(0.14)$ & $0.269(0.05)$ & $0.04(0.01)$ & $0.03(0.003)$ & $0.002(0.001)$ \\
$17: 40$ & $0.019(0.003)$ & $0.45(0.07)$ & $0.09(0.03)$ & $0.03(0.001)$ & $0.004(0.001)$ \\
$21: 57$ & ND & $0.415(0.08)$ & $0.08(0.03)$ & $0.02(0.003)$ & $0.004(0.001)$ \\
\hline
\end{tabular}

Glu uptake was low, but detectable, throughout the diel cycle (Table 4). Rates were about $0.03 \% \mathrm{~h}^{-1}$, yielding an average daily $\mathrm{N}$ turnover due to glu of $0.72 \%$ $\mathrm{d}^{-1}$ Glu concentrations in the culture medium ranged from about 0.02 to $0.06 \mu \mathrm{M}$. Therefore, the $0.03 \mu \mathrm{M}{ }^{15} \mathrm{~N}$ tracer additions represented 50 to $100 \%$ enrichments of the ambient glu concentration (Table 4). These high additions may have stimulated uptake and therefore the results should be considered as upper estimates. The uptake of glu did not correlate with the concentration of glu in the medium.

\section{Intracellular metabolite pools}

Intracellular pools of glu and gln increased during the light period in Trichodesmium IMS101 growing on medium without added $\mathrm{N}$ substrates (Fig. 5A). The highest concentrations were measured during the period of high $\mathrm{N}_{2}$ fixation. Intracellular concentrations of glu were more than 10-fold higher than gln concentrations during most of the day. There was a strong diel pattern in the $\mathrm{gln} / \mathrm{glu}$ ratio in Trichodesmium IMS101 (Fig. 5B). The gln/glu ratio rose to a peak of about 0.3 during and just after the period of highest $\mathrm{N}_{2}$ fixation. However, during the dark period, when there was no $N_{2}$ fixation, ratios decreased to about 0.1

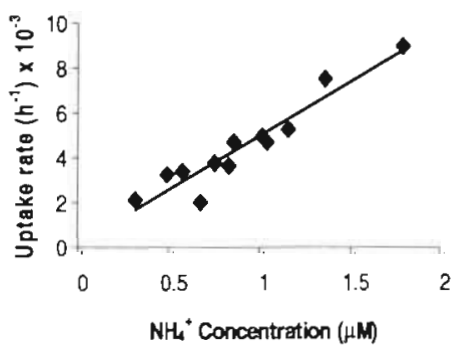

Fig. 4. $\mathrm{NH}_{4}{ }^{+}$uptake relative to concentrations of $\mathrm{NH}_{4}{ }^{+}$medsured in the culture rnedium

\section{GS activity}

Both GS transferase and GS biosynthetic activity decreased after the period of high $\mathrm{N}_{2}$ fixation in the afternoon (Fig. 6A). Similarly, the ratio of GS transferase/biosynthetic activity decreased from about 26 to 20 during the period when rates of $\mathrm{N}_{2}$ fixation were high (Fig. 6B) Late in the light period the ratio increased to values over 30 and remained about 30 during the dark period.
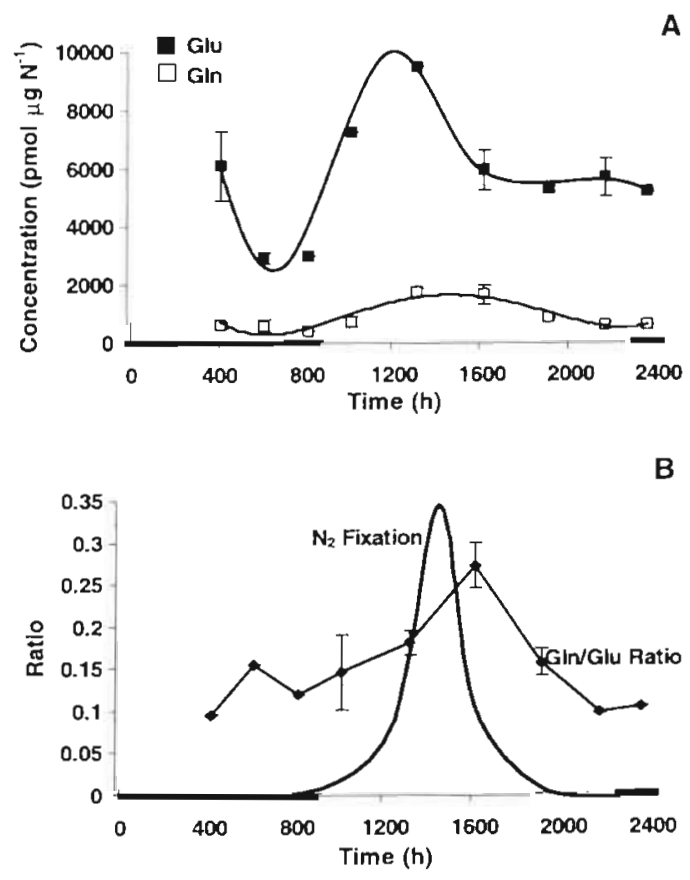

Fig. 5. Intracellular pools of (A) glu and gln and (B) the gln/glu ratio relative to the pattern of $\mathrm{N}_{2}$ fixation measured lactual values shown in Table 4 ) in Trichodesmium IMS101 grown on seawater medium depleted in combined $\mathrm{N}$ substrates. Bars on the $x$-axis indicate the dark period (darkness from 22:30 to $08: 30 \mathrm{~h}$ daily) 

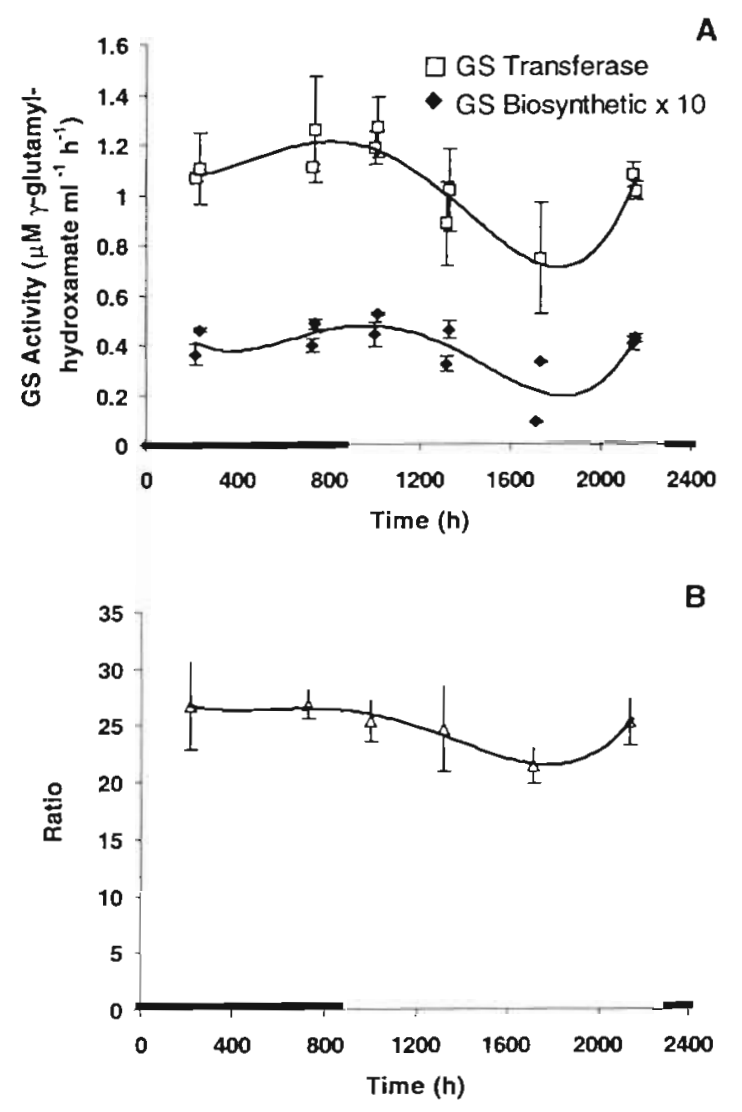

Fig. 6. (A) Glutamine synthetase (GS) transferase and biosynthetic activity and (B) the GS transferase/biosynthetic activity ratio relative to the pattern of $\mathrm{N}_{2}$ fixation measured (see Table 5 for data) in Trichodesmium IMS101 grown on seawater medium depleted in combined $N$ substrates. Bars on the $x$-axis indicate the dark period (darkness from 22:30 to 08:30 h daily)

\section{DISCUSSION}

\section{N utilization}

Rates of $\mathrm{N}_{2}$ fixation vary widely among populations of Trichodesmium from different oceanic regions (Goering et al. 1966, Saino 1977, Saino \& Hattori 1978). This may be because environmental factors, such as the availability of light and trace elements (e.g. Fe) and physiological factors, such as the growth stage, affect the rates at which $\mathrm{N}_{2}$ fixation proceeds (Carpenter \& Price 1976, Carpenter 1983a). Rates of combined $\mathrm{N}$ uptake by natural populations of Trichodesmium also vary among studies and sites (Table 5). As for $\mathrm{N}_{2}$ fixation, this variability may be due to differences in the nutritional status of populations or differences in their growth stage at the time of sampling.

Similar to previous reports, rates of $\mathrm{NO}_{3}{ }^{-}$uptake in our studies were low or undetectable in both natural populations of Trichodesmium and in cultured popula- tions growing on medium without added $\mathrm{N}$ (Table 5). An induction period for $\mathrm{NO}_{3}{ }^{-}$transport systems and $\mathrm{NO}_{3}{ }^{-}$assimilatory pathways or some minimum concentration may be necessary for $\mathrm{NO}_{3}{ }^{-}$utilization by natural and cultured populations (Flores \& Herrero 1994, Mulholland et al. 1999)

In general, the rates of urea uptake measured in this study (Table 5) were much higher than those measured by Carpenter \& McCarthy (1975). However these rates are consistent with rates reported by Saino (1977). We also measured high concentrations of urea within interfilamental spaces of colonies of Trichodesmium, suggesting that urea may be produced and taken up within the colonial assemblage. The source of this urea is not known. It is possible that urea is produced by grazers living in association with colonies. Bacterial production of urea has been measured in sediments (Pedersen et al. 1993) and seawater (Slawyk et al. 1990) but its production in association with Trichodesmium spp. colonies has not been measured.

Trichodesmium spp. have the highest capacities for $\mathrm{NH}_{4}{ }^{+}$and AA uptake. In natural populations of $T r i-$ chodesmium we measured $\mathrm{NH}_{4}{ }^{+}$uptake rates of 0.05 to $1.84 \% \mathrm{~h}^{-1}$. These rates are higher than those measured by Carpenter \& McCarthy (1975) but similar to the rates reported by Saino (1977) and Goering et al. (1966). Bacterial utilization and regeneration of $\mathrm{N}$ substrates, particularly $\mathrm{NH}_{4}{ }^{+}$and AA within incubation bottles can cause variability in measured rates of $\mathrm{N}$ uptake (Kirchman et al. 1989). While bacteria can consume $\mathrm{NH}_{4}{ }^{+}$, Kirchman et al. (1989) demonstrated that high DON (specifically as AA) concentrations stimulate net regeneration of $\mathrm{NH}_{4}{ }^{+}$by bacteria. Enrichment of interfilamental spaces with AA (Carpenter et al. 1992, Capone et al, 1994) may result in a net production of $\mathrm{NH}_{4}{ }^{+}$from AA in Trichodesmium communities. Bacteria occur in association with Trichodesmium colonies and are both directly attached to filaments and in loose association with colonies (Paerl et al. 1989). Carpenter \& Price (1977) estimated that $<1$ to $8.3 \%$ of Trichodesmium spp. trichomes were populated with bacteria.

Direct utilization of mixed AA by Trichodesmium spp. from the Eastern Caribbean Sea was observed by Paerl et al. (1989) using microautoradiography. AA can also be utilized indirectly. Extracellular AA oxidases have been identified in a variety of phytoplankton cultures (Palenik et al. 1988, Palenik \& Morel 1990a,b), bacterial populations in Long Island Sound (Pantoja et al. 1993), and in incubations containing Trichodesmium spp. (Mulholland et al. 1998). Extracellular oxidation of AA results in the liberation of $\mathrm{NH}_{4}{ }^{+}$which is subsequently available for utilization by cells. Glu uptake was much lower in cultured populations of $T r i-$ 
Table 5. Rates of N uptake by Trichodesmium spp. reported in the literature and those measured in these studies. Glu glutamate, Gln: glutamine, AA: amino acids, ND: not detected

\begin{tabular}{|c|c|c|c|c|c|c|}
\hline Substrate & Location & $\begin{array}{l}\text { Addition } \\
(\mu \mathrm{M})\end{array}$ & $\begin{array}{l}\text { Nuptake } \\
\left(\% \mathrm{~h}^{-1}\right)\end{array}$ & $\begin{array}{c}\text { Uptake rate } \\
\left(\mathrm{pg} \mathrm{N} \text { cell } l^{-1} \mathrm{~h}^{-1}\right)\end{array}$ & $\begin{array}{c}\text { Uptake rate } \\
\text { (pg } N \text { colony }{ }^{-1} h^{-1} \text { ) }\end{array}$ & Source \\
\hline $\mathrm{NH}_{4}^{+}$ & $\begin{array}{l}\text { W Sargasso Sea } \\
\text { W Sargasso Sea } \\
\text { W Sargasso Sea } \\
\text { N Atlantic } \\
\text { N Atlantic } \\
\text { NW Pacific } \\
\text { NW Pacific } \\
\text { NW Pacific } \\
\text { NW Pacific } \\
\text { NW Pacific } \\
\text { N Atlantic }\end{array}$ & $\begin{array}{c}0.13-20.4 \\
0.067 \\
14 \\
2 \\
2 \\
0.03 \\
0.05 \\
0.1-1.0 \\
2.0-10 \\
20 \\
0.03\end{array}$ & $\begin{array}{c}0.0006-0.018^{c} \\
0.005-0.014 \\
0.0042-0.0048^{c} \\
0.005-0.08 \\
0.51(\text { Bloom) } \\
0.01 \\
0.02 \\
0.035-0.23 \\
0.03-0.21 \\
2.0 \\
0.05-2.0\end{array}$ & $0.02-0.59$ & $\begin{array}{l}0.6-17.7^{b} \\
4.2-4.8^{b}\end{array}$ & $\begin{array}{l}\text { Carpenter \& McCarthy (1975) } \\
\text { Carpenter \& McCarthy (1975) } \\
\text { Carpenter \& McCarthy (1975) } \\
\text { Goering et al. (1966) } \\
\text { Goering et al. (1966) } \\
\text { Saino (1977) } \\
\text { Saino (1977) } \\
\text { Saino (1977) } \\
\text { Saino (1977) } \\
\text { Saino \& Hattori (1978) } \\
\text { Present study }\end{array}$ \\
\hline $\mathrm{NO}_{3}{ }^{-}$ & $\begin{array}{l}\text { W Sargasso Sea } \\
\text { W Sargasso Sea } \\
\text { N Atlantic } \\
\text { N Atlantic } \\
\text { NW Pacific } \\
\text { N Atlantic }\end{array}$ & $\begin{array}{c}0.13-20.4 \\
14 \\
2 \\
2 \\
10 \\
0.03\end{array}$ & $\begin{array}{c}-0 \\
0.00012-0.0003^{r} \\
0-0.02 \\
0.175(\mathrm{Bl} 100 \mathrm{~m}) \\
0.0026-0.0028 \\
\text { ND-0.0005 }\end{array}$ & $\begin{array}{c}-0 \\
0.004-0.01\end{array}$ & $\begin{array}{c}\sim^{\mathrm{b}} \\
0.12-0.3^{b}\end{array}$ & $\begin{array}{l}\text { Carpenter \& McCarthy (1975) } \\
\text { Carpenter \& McCarthy (1975) } \\
\text { Goering et al. (1966) } \\
\text { Goering et al. (1966) } \\
\text { Saino (1977) } \\
\text { Present study }\end{array}$ \\
\hline Urea & $\begin{array}{l}\text { W Sargasso Sea } \\
\text { W Sargasso Sea } \\
\text { NW Pacific } \\
\text { N Atlantic }\end{array}$ & $\begin{array}{c}0.13-20.4 \\
14 \\
10 \\
0.03\end{array}$ & $\begin{array}{c}-0 \\
0.00054-0.0006^{c} \\
0.0494-0.0534 \\
\text { ND }-0.2\end{array}$ & $\begin{array}{c}\sim 0 \\
0.018-0.02\end{array}$ & $\begin{array}{c}\sim 0^{b} \\
0.54-0.60^{b} \\
N D-420\end{array}$ & $\begin{array}{l}\text { Carpenter \& McCarthy (1975) } \\
\text { Carpenter \& McCarthy (1975) } \\
\text { Saino (1977) } \\
\text { Present study }\end{array}$ \\
\hline Glu & $\begin{array}{l}\text { NW Pacific } \\
\text { Caribbean } \\
\text { Caribbean } \\
\text { Caribbean } \\
\text { Present study }\end{array}$ & $\begin{array}{c}10 \\
0.07 \\
0.001 \\
0.001 \\
\text { N Atlantic }\end{array}$ & $\begin{array}{c}0.0085-0.0093 \\
<0.2 \\
0.0018-0.0053^{c} \\
0.025^{c} \\
0.03\end{array}$ & $0.0081-0.69$ & $\begin{array}{l}1.8-5.3(\mathrm{am}) \\
25(\mathrm{mid}-\mathrm{day}) \\
2.8-952\end{array}$ & $\begin{array}{l}\text { Saino (1977) } \\
\text { Capone et al. }(1994)^{\mathrm{d}} \\
\text { Carpenter et al. }(1992)^{\mathrm{e}} \\
\text { Carpenter et al. }(1992)^{\mathrm{e}}\end{array}$ \\
\hline Gln & $\begin{array}{l}\text { Caribbean } \\
\text { Caribbean }\end{array}$ & $\begin{array}{l}0.001 \\
0.001\end{array}$ & $\begin{array}{c}0.0001-0.00007^{c} \\
0.0025-0.005^{c}\end{array}$ & & $\begin{array}{c}0.1-0.07(\mathrm{am}) \\
2.5-5(\mathrm{mid}-\mathrm{day})\end{array}$ & $\begin{array}{l}\text { Carpenter et al. }(1992)^{\mathrm{e}} \\
\text { Carpenter et al. }(1992)^{\mathrm{e}}\end{array}$ \\
\hline $\begin{array}{l}\text { Glycine } \\
\text { AA }\end{array}$ & $\begin{array}{l}\text { N Atlantic } \\
\text { N Atlantic }\end{array}$ & $\begin{array}{c}2 \\
0.03\end{array}$ & $\begin{array}{c}0.02 \\
0.01-0.023^{r}\end{array}$ & & $2.3-410$ & $\begin{array}{l}\text { Goering et al. (1966) } \\
\text { Present study }\end{array}$ \\
\hline \multicolumn{7}{|c|}{ 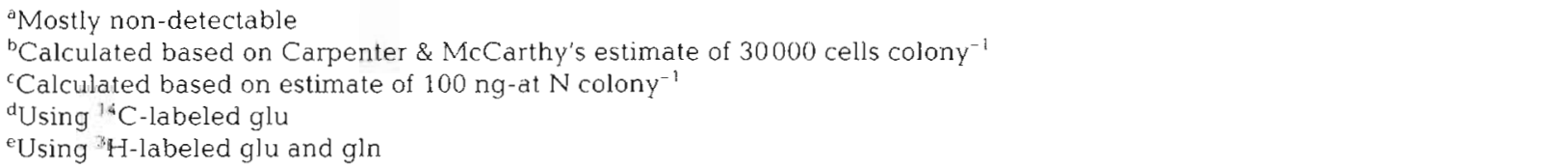 } \\
\hline
\end{tabular}

chodesmium. This may reflect the lower abundance of the microbes necessary for regenerating $\mathrm{NH}_{4}{ }^{+}$from glu in these populations.

We found that in natural populations of Trichodesmium spp., $K_{\mathrm{s}}+S_{\mathrm{n}}$ values for $\mathrm{NH}_{4}{ }^{+}$and glu were consistent with those reported previously (Table 6). Our $V_{\max }^{\prime}$ estimates for $\mathrm{NH}_{4}{ }^{+}$uptake were substantially higher than those previously reported. In cultures of Trichodesmium NIBB1067, apparent $V_{\max }$ decreased as incubation length increased, suggesting that recycling of nutrients, and consequent isotope dilution, may occur within the incubation bottles during longer incubations (Mulholland et al. 1999). Because our incubations were short ( 1 or $2 \mathrm{~h}$ ), isotope dilution was minimal during these experiments.
$\mathrm{N}$ metabolism

Intracellular $\mathrm{N}$ and $\mathrm{C}$ dynamics and the availability of substrates for $\mathrm{NH}_{4}{ }^{+}$assimilation have been implicated as important factors affecting the regulation of $\mathrm{N}_{2}$ fixation and $\mathrm{N}$ metabolism in a variety of bacteria and cyanobacteria (Guerrero \& Lara 1987, Flores \& Herrero 1994). Gln/glu ratios have been utilized as an index of cellular C:N status and $N$ limitation in a variety of microalgae (Flynn et al. 1989, Flynn \& Gallon 1990). Flynn et al. (1989) suggested that phytoplankton cells with intracellular gln/glu ratios $>0.5$ are $\mathrm{N}$-replete while those with ratios of $<0.2$ are $N$-depleted. Applying these criteria, Trichodesmium spp. cells are rarely $\mathrm{N}$-depleted. We observed $\mathrm{gln} / \mathrm{glu}$ ratios of 0.6 during 
Table 6 . Values of $K_{\mathrm{s}}(\mu \mathrm{M})$ and $V_{\mathrm{max}}\left(\% \mathrm{~N} \mathrm{~h}^{-1}\right)$ reported for various $\mathrm{N}$ sources and those measured in these studies

\begin{tabular}{|lccll|}
\hline Substrate & $\begin{array}{c}K_{s} \\
(\mu \mathrm{M})\end{array}$ & $\begin{array}{c}V_{\max } \\
\left(\% \mathrm{~h}^{-1}\right)\end{array}$ & Location & Source \\
\hline $\mathrm{NH}_{4}{ }^{+}$ & 6.74 & $0.177^{\mathrm{a}}$ & W Sargasso Sea & $\begin{array}{l}\text { Carpenter \& } \\
\text { McCarthy (1975) }\end{array}$ \\
& $\begin{array}{l}0.3 \text { to } 12 \\
3.1 \text { to } 3.9\end{array}$ & $\begin{array}{c}0.045 \text { to } 0.25 \\
2.2\end{array}$ & $\begin{array}{l}\text { NW Pacific } \\
\text { NAtlantic }\end{array}$ & $\begin{array}{l}\text { Saino (1977) } \\
\text { Present study }\end{array}$ \\
$\mathrm{NO}_{3}{ }^{-}$ & 0 to 2 & 0.02 & N Atlantic & Present study \\
Gilutamate & $\begin{array}{c}1.59 \text { to } 3.24 \\
1.8 \text { to } 4.4\end{array}$ & 0.45 & N Atlantic & $\begin{array}{l}\text { Capone et al. (1994) } \\
\text { Present study }\end{array}$ \\
Amino acids 0.12 to 1.43 & 0.45 to 0.55 & N Atlantic & Present study \\
\hline
\end{tabular}

therefore had the potential to assimilate enough $\mathrm{N}$ to turn over their cell $\mathrm{N}$ at least 50 times $\mathrm{d}^{-1}$, suggesting that $\mathrm{N}$ assimilation does not limit the rate of $\mathrm{N}$ utilization by cells, even when $\mathrm{N}_{2}$ fixation rates are maximal.

Some investigators have reported that only a subset $(<10$ to $15 \%)$ of cells within a colony or along a filament of Trichodesmium contain nitrogenase and are capable of fixing $\mathrm{N}_{2}$ (Janson et al. 1994, Fredriksson \& Bergman 1995, 1997, Bergman 1999). Immuno-gold labeling indicates that while the GS enzyme is present in all cells within colonies, its concentrations are higher in cells containing periods of $\mathrm{N}_{2}$ fixation, consistent with the earlier observations by Capone et al. (1994). Gln/glu ratios of about 0.2 were observed during the dark period. In these studies, the magnitude and timing of the daily peak in gln/glu ratios varied among sites and populations, consistent with the variability reported by Capone et al. (1994). The gln/akg ratio exhibited a similar pattern to the $\mathrm{gln} / \mathrm{glu}$ ratio, suggesting that the gln/glu ratio may be a good indicator of cellular $N$ status.

The higher gln/glu ratios observed in Trichodesmium colonies collected near the surface waters relative to colonies collected from depth may indicate light limitation of $\mathrm{N}_{2}$ fixation. Higher rates of photosynthesis by surface populations may provide energy to support higher rates of $\mathrm{N}_{2}$ fixation, resulting in higher gln/glu and gln/akg ratios in these populations. The high $\mathrm{gln} / \mathrm{glu}$ ratios observed in surface samples in this study were comparable to ratios reported by Capone et al. (1994) in samples collected from about $5 \mathrm{~m}$ depth. We observed lower gln/glu ratios in colonies collected from between 20 and $30 \mathrm{~m}$ depth and in cultures of $T_{r i-}$ chodesmium IMS101 (a maximum of about 0.3). Cultures were grown under low light levels relative to those measured in tropical surface waters and $N_{2}$ fixation may be light limited in these culture systems.

Assimilation of fixed $\mathrm{N}_{2}$ via $\mathrm{GS}$ does not appear to limit the rate of $\mathrm{N}_{2}$ fixation. Rates of GS transferase and GS biosynthetic activity by Trichodesmium spp. increased in the afternoon when high rates of $\mathrm{N}_{2}$ fixation and high gln/glu ratios were observed. The absence of a strong diel cycle of GS transferase activity suggests that the GS pool is conserved in Trichodesmium.

Our results indicate that Trichodesmium colonies have an excess biosynthetic capacity via GS. Based on an average $5 \mu \mathrm{g}$ protein colony ${ }^{-1}$, we calculated a maximum biosynthetic capacity of $0.72 \mu \mathrm{Mol} N$ assimilation colony $\mathrm{y}^{-1} \mathrm{~d}^{-1}$. Our average $\mathrm{N}$ biomass for a colony was 7.15 to $14.3 \mathrm{nmol} \mathrm{N}(0.1$ to $0.2 \mu \mathrm{g} \mathrm{N})$. Colonies nitrogenase (Carpenter et al. 1992). This pattern is consistent with that observed in the genus Anabaena. For these species, high GS activities are associated with $\mathrm{N}_{2}$-fixing heterocysts. Rapid assimilation of $\mathrm{NH}_{4}{ }^{+}$ and transport of gln out of the $\mathrm{N}_{2}$-fixing regions is thought to be important for preventing feedback inhibition of GS and nitrogenase by accumulated $N$ metabolites (Bergman et al. 1985, Guerrero \& Lara 1987).

GS biosynthetic/transferase activity ratio decreased during the period of maximum $\mathrm{N}_{2}$ fixation. Changes in the ratio between biosynthetic and transferase activity in enteric bacteria is attributed to changes in the adenylylation state and consequent biosynthetic activity of the GS enzyme (Lee et al. 1988). We found that the ratio of GS transferase/biosynthetic activity varied by about 20 to $30 \%$ over a diel cycle. These changes may reflect an increase in the relative biosynthetic capacity of the GS pool associated with nitrogenase.

Tumer et al. (1983) found that there were different promoters for transcribing the gene encoding GS during growth on fixed $\mathrm{N}$ and molecular $\mathrm{N}_{2}$ in Anabaena 7120, a heterocystous $\mathrm{N}_{2}$ fixer. They suggested that there are 2 , separately regulated pools of GS: a general pool that is conserved to assimilate $N$ as it is encountered, and a nitrogenase-linked pool that is synthesized and activated in conjunction with nitrogenase. In Trichodesmium, GS mRNA transcript abundance exhibits 2 peaks, one before dawn corresponding with peak nitrogenase mRNA transcription (Wyman et al. 1996), and one during the late afternoon (Kramer et al. 1996). This observation is consistent with the idea that there may be 2 , separately regulated pools of GS in Trichodesmium. If 2 pools of GS are present, the small changes in total filament or may be significant in terms of the capacity for assimilating $\mathrm{N}$ from $\mathrm{N}_{2}$ fixation. colony GS activity that we observed over a diel cycle 


\section{$\mathrm{N}$ budgets}

Based on total measured $\mathrm{N}$ utilization $\left(\mathrm{N}_{2}\right.$ fixation plus $\mathrm{NH}_{4}{ }^{+}$and glu uptake), an $\mathrm{N}$-based turnover time of about 3 to $5 \mathrm{~d}$ was calculated for Trichodesmium IMS101 during exponential phase growth. When only $\mathrm{N}_{2}$ fixation was considered, $9 \mathrm{~d}$ were required for a doubling of the culture biomass. At similar biomass levels, Trichodesmium NIBB1067 doubles in $8 \mathrm{~d}$ and is in late exponential growth phase (Mulholland et al. 1999).

Independent of absolute growth demands, we calculated a daily $\mathrm{N}$ utilization budget for Trichodesmium IMS101 by integrating the relative contribution of 3 $\mathrm{N}$ sources $\left(\mathrm{N}_{2}, \mathrm{NH}_{4}{ }^{+}\right.$, and glu) to the total measured $\mathrm{N}$ turnover over a diel cycle (Fig. 7). Of the total daily $\mathrm{N}$ utilization, $72 \%$ was attributed to $\mathrm{NH}_{4}{ }^{+}$uptake, $23 \%$ was due to $\mathrm{N}_{2}$ fixation and $4 \%$ was from glu uptake. Because our cultures of Thichodesmium were closed systems to which no combined $\mathrm{N}$ had been added, all of the $\mathrm{N}$ used to support net growth must ultimately be derived from $\mathrm{N}_{2}$ fixation.

Based on C:N ratios observed in colonies of Trichodesmium (Carpenter 1983a), the stoichiometry of C and $\mathrm{N}_{2}$ fixation appear to be out of balance. For instance, Capone et al. (1998) calculated that $\mathrm{N}_{2}$ fixation provided $<20 \%$ of the daily $\mathrm{N}$ demand necessary to balance the observed $\mathrm{C}$ utilization by Trichodesmium populations within an Indian Ocean bloom. However, the low $\delta^{15} \mathrm{~N}$ of these populations suggested that $\mathrm{N}_{2}$ fixation was still the primary $\mathrm{N}$ source for these populations. Other imbalances have been observed in
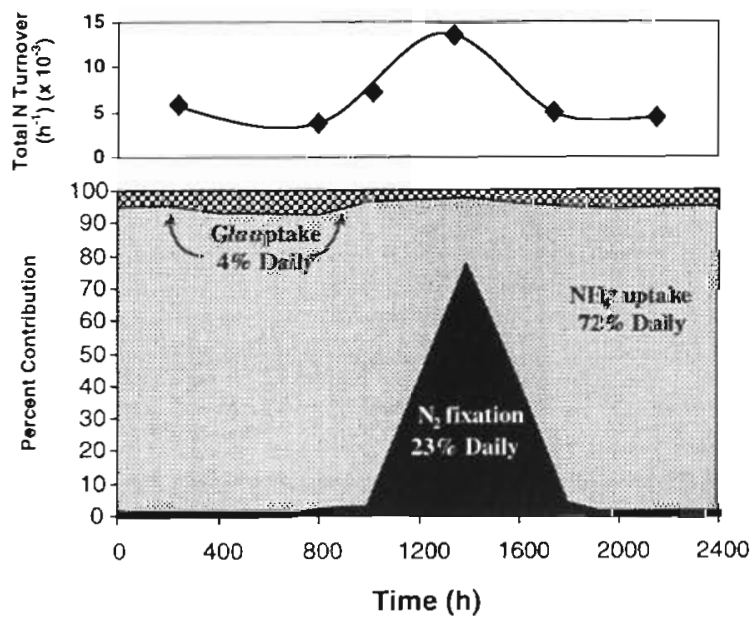

Fig. 7. Total daily $N$ turnover by Trichodesmium IMS101 growing on medium depleted in combined $N$ substrates (upper panel). Percent contribution of glu, $\mathrm{NH}_{4}{ }^{*}$ and $\mathrm{N}_{2}$ fixation to the dailly $\mathrm{N}$ turnover. $\mathrm{N}_{2}$ fixation $\mathrm{N}$ and glu and $\mathrm{NH}_{4}{ }^{+}$ uptake rates were measured over a diel cycle and these rates were integrated aver a $24 \mathrm{~h}$ day productivity estimates based on $\mathrm{N}_{2}$ fixation versus C fixation in natural populations of Trichodesmium. In the Caribbean Sea, Carpenter \& Price (1977) estimated that Trichodesmium spp. represented $20 \%$ of the carbon productivity but only $8 \%$ of the system's $\mathrm{N}$ demand was supplied by $\mathrm{N}_{2}$ fixation. In Trichodesmium IMS101 cultures, we calculated that $\mathrm{C}$ and $\mathrm{N}$ turnover were nearly balanced relative to the reported C:N ratios (Carpenter 1983a, Carpenter \& Romans 1991) only when we consider both $N_{2}$ fixation and $\mathrm{NH}_{4}{ }^{+}$uptake as components of total $\mathrm{N}$ turnover. The $\mathrm{N}$ demand calculated from short-term $\mathrm{C}$ productivity measurements may overestimate $\mathrm{N}$ requirements for net growth. In cultures of Trichodesmium grown on medium without added $\mathrm{N}$ sources, $\mathrm{N}_{2}$ fixation was a good indicator of net growth

Observations of high $\mathrm{N}$ turnover rates relative to rates of $\mathrm{N}_{2}$ fixation combined with low $\delta^{15} \mathrm{~N}$ signatures may be reconciled if there is a tight coupling between $\mathrm{N}_{2}$ fixation, $\mathrm{NH}_{4}{ }^{+}$release or $\mathrm{N}$ regeneration and uptake of the low $\delta^{15} \mathrm{NH}_{4}{ }^{+}$derived from recently fixed $\mathrm{N}_{2}$. A.t present, there are no determinations of the $\delta^{15} \mathrm{~N}$ signature of the $\mathrm{NH}_{4}{ }^{+}$pools in these systems to confirm this speculation. Zooplankton grazing on Trichodesmium and other $\mathrm{N}_{2}$-fixing organisms may contribute to an isotopically light $\mathrm{NH}_{4}^{+}$pool in the upper water column. Checkley \& Miller (1989) have observed that oceanic zooplankton excrete $\mathrm{NH}_{4}{ }^{+}$that is isotopically lighter than their body values.

Carpenter et al. (1999) reported that the relative contribution of $\mathrm{NH}_{4}^{+}$to the total $\mathrm{N}$ nutrition increased over time in a bloom of an $\mathrm{N}_{2}$-fixing symbiosis, Hemiaulus/Richelia. However, the population retained a light $\delta^{15} \mathrm{~N}$ signature. We speculate that Trichodesmium may exhibit a similar pattern whereby populations alleviate $\mathrm{N}$ limitation initially by fixing $\mathrm{N}_{2}$. Subsequently, newly fixed $\mathrm{N}$ may be recycled as $\mathrm{NH}_{4}{ }^{+}$and DON. These $\mathrm{N}$ sources may be available for uptake by cells to support growth. Similarly, the relative proportions of $\mathrm{N}$ uptake and $\mathrm{N}_{2}$ fixation to total $\mathrm{N}$ turnover may change over a growth cycle in cultures of Trichodesmium. Experiments are underway to test this hypothesis.

\section{Community $\mathrm{N}$ dynamics}

A high affinity for $\mathrm{NH}_{4}{ }^{+}$, coupled with the positive correlation between $\mathrm{NH}_{4}{ }^{+}$concentration and $\mathrm{NH}_{4}{ }^{+}$ uptake in cultures of Trichodesmium IMS101, suggest that $\mathrm{NH}_{4}{ }^{+}$release and uptake may be tightly coupled within Trichodesmium spp. communities. Tight coupling between $\mathrm{N}_{2}$ fixation and $\mathrm{NH}_{4}^{+}$uptake and a capacity for concomitant $\mathrm{N}_{2}$ fixation and $\mathrm{N}$ uptake may be an important adaptation whereby Trichodesmium 
spp. can support growth and maintain their biomass in extremely oligotrophic environments. In closed culture systems, $\mathrm{NH}_{4}{ }^{+}$is retained in the system and may accumulate in the culture medium for utilization by the cultured organism. By contrast, in natural systems that are open, $\mathrm{NH}_{4}{ }^{+}$and $\mathrm{DON}$ produced by and released from cells or regenerated within colonial associations may diffuse away from cells and become part of the ambient nutrient pool available for utilization by all org-anisms in the community. Sometimes, high concentrations of $\mathrm{NH}_{4}{ }^{+}$and glu were measured in the interfilamental areas of Trichodesmium colonies collected from natural populations (Capone et al. 1994, Table 2). This suggests that colonies may retain nutrients in microzones thereby preventing their diffusion away from cells.

There are a variety of potential $\mathrm{NH}_{4}{ }^{+}$sources within the Trichodesmium consortia. AA and DON are released by Trichodesmium during growth (Capone et al. 1994, Glibert \& Bronk 1994). AA oxidase activity associated with Trichodesmium spp. can liberate $\mathrm{NH}_{4}{ }^{+}$from these compounds (up to $20 \mathrm{pmol} \mathrm{N}$ colony $^{-1} \mathrm{~h}^{-1}$ ) (Mulholland et al. 1998). Bacteria can also regenerate $\mathrm{NH}_{4}{ }^{+}$in environments rich in $\mathrm{N}$-rich dissolved organic material (Kirchman et al. 1989). Nausch (1996) estimated that 0.32 to $15 \mathrm{nmol} \mathrm{N}$ colony $^{-1} \mathrm{~h}^{-1}$ was released by peptidase and $\beta$-glucosamidase activity associated with bacteria residing among Trichodesmium spp. colonies. Zooplankton grazing can also result in rapid $\mathrm{NH}_{4}{ }^{+}$recycling. O'Neil et al. (1996) reported $\mathrm{NH}_{4}{ }^{+}$release rates of $2 \mathrm{nmol} \mathrm{N}$ copepod ${ }^{-1} \mathrm{~h}^{-1}$ from Macrosetella gracilis grazing on Trichodesmium spp. They estimated that 33 to $45 \%$ of a $T$. thiebautii colony and more than $100 \%$ of the $\mathrm{N}_{2}$ fixed $\mathrm{d}^{-1}$ could be consumed by grazing each day. The $N$ content of a single colony is on average about $100 \mathrm{ng} \mathrm{N}_{\text {colony }}{ }^{-1}$. Trichodesmium can also contain cyanophages (Ohki 1999). Viral cell lysis causes cells to burst, releasing the contents of the cell (including $\mathrm{N}$ metabolites and organic compounds) into the environment. Our analysis of intracellular $\mathrm{NH}_{4}^{+}\left(0.57\right.$ to $3.42 \mathrm{nmol}$ colony $\left.{ }^{-1}\right)$, glu ( 1 to $5 \mathrm{nmol}$ colony $\left.{ }^{-1}\right)$, and gln $\left(0.2\right.$ to $1 \mathrm{nmol}$ colony $\left.{ }^{-1}\right)$ concentrations would suggest that 3 to $9.5 \mathrm{nmol} \mathrm{colony}^{-1}$ of these combined $N$ sources could be released when cells lyse. Based on the high rates of $N$ regeneration estimated from bacterial processes and grazing associated with Trichodesmium spp. colonies, sufficient $\mathrm{NH}_{4}{ }^{+}$substrates are available to support the rates of $\mathrm{NH}_{4}{ }^{+}$uptake reported here (up to 55 pmol $\mathrm{N}_{\text {colony }}{ }^{-1}$ $h^{-1}$ ).

In contrast to results reported by Glibert \& Banahan (1988), our results also support a substantive direct release of $\mathrm{NH}_{4}{ }^{+}$by Trichodesmium despite excess biosynthetic capacity via GS. In this study, $\mathrm{NH}_{4}{ }^{+}$con- centrations increased to almost $2.0 \mu \mathrm{M}$ in cultures grown on medium without added $\mathrm{N}$ substrates. Saino (1977) also observed release of $\mathrm{NH}_{4}{ }^{+}$from Trichodesmium colonies over time.

\section{Conclusions}

The previously reported low rates of combined $N$ uptake by Trichodesmium (Carpenter \& McCarthy 1975, Glibert \& Banahan 1988) and their low $\delta^{15} \mathrm{~N}$ signature (Carpenter et al. 1997) have led to the general conclusion that $\mathrm{N}_{2}$ fixation is the primary mode of $\mathrm{N}$ acquisition by these species (Carpenter et al. 1997). Our results indicate that, while $\mathrm{N}_{2}$ fixation may meet the bulk of the cellular $\mathrm{N}$ demand for net growth, Trichodesmium spp. assemblages can concurrently utilize combined $\mathrm{N}$ (mainly $\mathrm{NH}_{4}{ }^{+}$and DON) and fix $\mathrm{N}_{2}$ at high rates. If only 10 or $15 \%$ of Trichodesmium cells are able to fix $\mathrm{N}_{2}$, the release of fixed $\mathrm{N}_{2}$ and its subsequent uptake may be an important mechanism for transporting $\mathrm{N}$ among cells that are fixing $\mathrm{N}_{2}$ and those that are not.

Acknowledgements. We thank J. Burns, C. Shoemaker, G Yellin, and S. Jefferson for their assistance at sea and in the lab. Hal Schreier and Jack Meeks provided helpful insights regarding GS assays and we thank them. We thank Lee Bebout for providing us with Trichodesmium IMS101 and helping us to keep it alive. We also benefited greatly from the support, cooperation, and companionship of the officers and crew of the RV 'Seward Johnson' as well as the other members of the shipboard scientific party. D.G.C. was supported by NSF grants.

\section{LITERATURE CITED}

Bergman B (1999) Distribution of nitrogenase in the marine non-heterocystous cyanobacterium Trichodesmium. In: Charpy L, Larkum AWD (eds) Marine cyanobacteria. Bulletin de l'Institut Océanographique, Monaco, Special Issue No. 19 (in press)

Bergman B, Lindblad P, Pettersson A, Renstrom E, Tiberg E (1985) Immuno-gold localization of glutamine synthetase in a nitrogen-fixing cyanobacterium (Anabaena cylindrica). Planta 166:329-334

Bronk DA, Glibert PM, Ward BB (1994) Nitrogen uptake, dissolved organic nitrogen release, and new production. Science 265:1843-1846

Capone DG (1993) Determination of nitrogenase activity in aquatic samples using the acetylene reduction procedure. In: Kemp PF, Sherr BF, Sherr EB, Cole JJ (eds) Handbook of methods in aquatic microbial ecology. Lewis Publishers, New York, p 621-631

Capone DG, O'Neil JM, Zehr J, Carpenter EJ (1990) Basis for diel variation in nitrogenase activity in the marine planktonic cyanobacterium Trichodesminm thiebautii. Appl Environ Microbiol 56:3532-3536

Capone DG. Ferrier MD, Carpenter EJ (1994) Amino acid 
cycling in colonies of the planktonic marine cyanobacterium, Trichodesmium thiebautii. Appl Environ Microbiol 60:3989-3995

Capone DG, Zehr JP, Paerl HW, Bergman B, Carpenter EJ (1997) Trichodesmium, a globally significant marine cyanobacterium. Science 276:1221-1229

Capone DG, Subramaniam A, Montoya JP, Voss M. Humborg C, Johansen AM, Siefert RL, Carpenter E J (1998) An extensive bloom of the $\mathrm{N}_{2}$-fixing cyanobacterium $\mathrm{Tr}$ chodesmium erythraeum in the central Arabian Sea. Mar Ecol Prog Ser 172:281-292

Carpenter EJ (1983a) Physiology and ecology of marine planktonic Oscillatoria (Trichodesmium) Mar Biol Lett 4:69-85

Carpenter EJ (1983b) Nitrogen fixation by marine Oscillatoria (Trichodesmium) in the world's oceans. In: Carpenter EJ, Capone DG (eds) Nitrogen in the marine environment. Academic Press, New York, p 65-103

Carpenter EJ, McCarthy JJ (1975) Nitrogen fixation and uptake of combined nitrogenous nutrients by Oscillatoria (Trichodesmium) thiebautii in the western Sargasso Sea. Limnol Oceanogr 20:389-401

Carpenter EJ, Price CC (1976) Marine Oscillatoria (Trjchodesmium): explanation for aerobic nitrogen fixation without heterocysts. Science 191:1278-1280

Carpenter EJ, Price CC (1977) Nitrogen fixation, distribution, and production of Oscillatoria (Trichodesmium) spp. In the western Sargasso and Caribbean Seas. Limnol Oceanogr $22: 60-72$

Carpenter EJ, Romans K (1991) Major role of the cyanobacterium Trichodesmium in nutrient cycling in the North Atlantic Ocean. Science 254:1356-1358

Carpenter EJ, Bergman B, Dawson R, Siddiqui PJA, Soderback $E_{1}$ Capone DG (1992) Glutamine synthetase and nitrogen cycling in colonies of the marine diazotrophic cyanobacteria Trichodesmium spp. Appl Environ Microbiol 58:3122-3129

Carpenter EJ, Capone DG, Fry B, Harvey HR (1997) Biogeochemical tracers of the marine cyanobacterium Trichodesmium. Deep-Sea Res 44:27-38

Carpenter EJ, Montoya JP, Burns J, Mulholland MR, Subramaniam A, Capone DG (1999) Extensive bloom of a $\mathrm{N}_{2}$ fixing diatom/cyanobacterial association in the tropical Atlantic Ocean. Mar Ecol Prog Ser 185:273-283

Checkley DM, Miller CA (1989) Nitrogen isotope fractionation by oceanic zooplankton. Deep-Sea Res 36:1449-1456

Chen YB, Zehr JP, Mellon M (1996) Growth and nitrogen fixation of the diazotrophic filamentous nonheterocystous cyanobacterium Trichodesmium sp. IMS101 in defined media: evidence for a circadian rhythm. J Phycol 32:916-923

Cowie GL, Hedges JI (1992) Improved amino acid quantification in environmental samples: charge-matched recovery standards and reduced analysis time. Mar Chem 37: $223-238$

Devassy VP (1987) Trichodesmium red tides in the Arabian Sea. In: Qasim SZ (ed) Contributions in marine sciences, Sastyabdapurti felicitation Volume. p 61-66

Eppley RW, Petersen BJ (1979) Particulate organic matter flux and planktonic new production in the deep ocean. Nature 282:677-680

Flores E, Herrero A (1994) Assimilatory nitrogen metabolısm and its regulation. In: Bryant DA (ed) The molecular biology of cyanobacteria. Kluwer Academic Publishers, Dordrecht, p 487-517

Flynn KJ (1988) Some practical aspects of measurements of dissolved free amino acids in natural waters and within microalgae by the use of HPLC. Chem Ecol 3:369-293
Flynn KJ (1990) The determination of nitrogen status in microalgae. Mar Ecol Prog Ser 61:297-307

Flynn KJ, Gallon JR (1990) Changes in intracellular and extracellular $\alpha$-ammo acids in Gloeothece during $\mathrm{N}_{2}$-fixation and following addition of ammonium. Arch Microbiol 153:574-579

Flynn KJ, Dickson DMJ, Al-Amoudi OA (1989) The ratio of glutamine:glutamate in microalgae: a biomarker for $\mathrm{N}$ status suitable for use at natural cell densities. J Plankton Res 11:165-170

Fredriksson C, Bergman B (1995) Nitrogenase quantity varies diurnally in a subset of cells within colonies of the nonheterocystous cyanobacteria Trichodesmium spp. Microbiology 141:2471-2478

Fredriksson C, Bergman B (1997) Ultrastructural characterisation of cells specialised for nitrogen fixation in a non-heterocystous cyanobacterium, Trichodesmium spp. Protoplasma 197:76-86

Friederich GO, Whitledge TE (1972) Autoanalyzer procedures for nutrients. In: Pavlou SP (ed) Phytoplankton growth dynamics, Vol 1 University of Washington Special Report 52, Seattle, WA

Glibert PM, Banahan S (1988) Uptake of combined nitrogen sources by Trichodesmium and pelagic microplankton in the Caribbean Sea: comparative uptake capacity and nutritional status. EOS 69:1089

Glibert PM, Bronk DA (1994) Release of dissolved organic nitrogen by marine diazotrophic cyanobacteria, Trichodesmium spp. Appl Environ Microbiol 60(11):3996-4000

Glibert PM, Capone DG (1993) Mineralization and assimilation in aquatic, sediment, and wetland systems. In: Knowles $\mathrm{R}$, Blackburn TH (eds) Nitrogen isotope techniques. Academic Press, Inc, New York, p 243-271

Goering JJ, Dugdale RC, Menzel DW (1966) Estimates of in situ rates of nitrogen uptake by Trichodesmium $\mathrm{sp}$. in the tropical Atlantic Ocean. Limnol Oceanogr 11:614-620

Guerrero MG, Lara C (1987) Assimilation of inorganic nitrogen. In: Fay $\mathrm{P}$, Van Baalen $\mathrm{C}$ (eds) The cyanobacteria. Elsevier Science Publishers, New York, p 163-186

Janson S, Carpenter EJ, Bergman B (1994) Compartmentalisation of nitrogenase in a non-heterocystous cyanobacterium: Trichodesmium contortum. FEMS Microbiol Lett $118: 9-14$

Karl DM, Letelier R, Hebel DV, Bird DF, Winn CD (1992) Trichodesmium blooms and new nitrogen in the North Pacific Gyre. In: Carpenter EJ, Capone DG, Rueter JG (eds) Marine pelagic cyanobacteria:Trichodesmium and other diazotrophs. Kluwer Academic Publishers, Dordrecht, p 219-237

Kirchman DL, Keil RG, Wheeler PA (1989) The effect of amino acids on ammonium utilization and regeneration by heterotrophic bacteria in the subarctic Pacific. Deep-Sea Res 36:1763-1776

Kramer JG, Wyman M, Zehr JP, Capone DG (1996) Diel variability in transcription of the structural gene for glutamine synthetase $(g \ln A)$ in natural populations of the marine diazotrophx cyanobacterum Trichodesmium thiebautii. FEMS Microbiol Ecol 21:187-196

Lee KY, Joseph CM, Meeks JC (1988) Glutamine synthetase specific activity and protein concentration in symbiotic Anabaena associated with Azolla caroliniana. Antonie Leeuwenhoek 54:345-355

Lowry OH, Passonneau JV (1972) A flexible system of enzy. matic analysis. Academic Press, Inc., New York.

Lowry OH, Carter J, Ward JB, Glaser L (1971) The effect of carbon and nitrogen sources on the level of metabolic intermediates in Escherichia coli. J Biol Chem 246:6511-6521. 
Mague TH, Mague FC, Holm-Hansen O (1977) Physiology and chemical composition of nitrogen-fixing phytoplankton in the central North Pacific Ocean. Mar Biol 41 $213-227$

Marumo R (1975) An outline of studies in the community of marine pelagic blue-green algae. In: Marumo R (ed) Studies on the community of marine pelagic blue-green algae 1972-1974. Ocean Research Institute, Tokyo, p 1-16

McCarthy JJ, Carpenter EJ (1979) Oscillatoria (Trichodesmium) thiebautii (Cyanophyta) in the central North Atlantic Ocean. J Phycol 15:75-82

Mulholland MR, Glibert PM, Berg GM, Van Heukelem L Pantoja S, Lee C (1998) Extracellular amino acid oxidation by microplankton: a cross-ecosystem comparison. Aquat Microb Ecol 15:141-152

Mulholland MR, Ohki K, Capone DG (1999) N utilization and metabolism relative to patterns of $\mathrm{N}_{2}$ fixation in cultures of Trichodesmium NIBB1067. J Phycol (in press)

Nausch M (1996) Microbial activities on Trichodesmium colonies. Mar Ecol Prog Ser 141:173-181

Ohki K (1999) A possible role of temperate virus(es) in the regulation of Trichodesmium biomass. In: Charpy L, Larkum AWD (eds) Marine cyanobacteria. Bulletin de l'Institut Océanographique, Monaco, Special Issue No. 19 (in press)

O'Neil JM, Metzler PM, Glibert PM (1996) Ingestion of ${ }^{15} \mathrm{~N}_{2}$ labelled Trichodesmium spp. and ammonium regenera. tion by the harpacticoid copepod Macrosetella gracilis. Mar Biol 125:89-96

Paerl HW, Bebout BM. Prufert LE (1989) Bacterial associations with marine Oscillatoria sp. (Trichodesmium sp.) populations: ecophysiological implications. J Phycol 25:773-784

Palenik BP, Morel FMM (1990a) Amino acid utilization by marine phytoplankton: a novel mechanism. Limnol Oceanogr 35:260-269

Palenik BP, Morel FMM (1990b) Comparison of cell-surface L-amino acid oxidases from several marine phytoplankton. Mar Ecol Prog Ser 59:195-201

Palenik BP, Kieber DJ, Morel FMM (1988) Dissolved organic nitrogen use by phytoplankton: the role of cell-surface enzymes. Biol Oceanogr 6:347-354

Pantoja S, Lee C (1994) Cell-surface oxidation of amino acids in seawater. Limnol Oceanogr 39:1718-1726

Pantoja S, Lee C, Marecek JF, Palenik BP (1993) Synthesis and use of fluorescent molecular probes for measuring cell-surface enzymatic oxidation of amino acids and amines in seawater. Anal Biochem 211:210-218

Editorial responsibility: Kenneth Tenore /Contributing Editor), Solomons, Maryland, USA
Pedersen H, Lomstein BA, Blackburn TH (1993) Evidence for bacterial urea production in marine sediments. FEMS Microbiol Ecol 12:51-59

Prufert-Bebout L, Paerl HW, Lassen C (1993) Growth, nitrogen fixation, and spectral attenuation in cultivated Trichodesmium species. Appl Environ Microbiol 59(5): $1367-1375$

Saino T (1977) Biological nitrogen fixation in the ocean with emphasis on the nitrogen fixing blue-green alga Trichodesmium and its significance in the nitrogen cycling in the low latitude sea areas. PhD thesis, Ocean Research Institute, University of Tokyo

Saino T, Hattori A (1978) Diel variation in nitrogen fixation by a marine blue-green alga, Trichodesmium thiebautii. Deep-Sea Res 25:1259-1263

Senior PJ (1975) Regulation of nitrogen metabolism in Escherichia coli and Klebsiella aerogenes: studies with the continuous-culture technique. J Bacteriol 123:407-418

Slawyk G, Rodier M (1988) Biosynthetically active glutamine synthetase in the marine diatom Phaeadactylum tricornutum: optimization of the forward-reaction assay. Mar Biol 97:269-274

Slawyk G, Raimbault P, L'Helguen S (1990) Recovery of urea nitrogen from seawater for measurement of $15 \mathrm{~N}$ abundance in urea regeneration studies using the isotope. dilution approach. Mar Chem 30:343-362

Stadtman ER, Smyrniotis PZ, Davis TN, Wittenberger MF (1979) Enzymatic procedures for determining the average state of adenylylation of Escherichia coli glutamine synthetase. Anal Biochem 95:275-285

Thoresen SS, Dortch Q. Ahmed SI (1982) Comparison of methods for extracting intracellular pools of inorganic nitrogen from marine phytoplankton. J Plankton Res 4: $695-704$

Tumer NE, Robinson SJ, Haselkorn R (1983) Different promoters for the Anabaena glutamine synthetase gene during growth using molecular or fixed nitrogen. Nature 306:337-342

Wyman M, Zehr JP, Capone DG (1996) Temporal variability in nitrogenase gene expression in a natural population of the marine cyanobacterium Trichodesmium thiebautii. Appl Environ Microbiol 62:1073-1075

Zehr JP, Wyman M, Miller V, Duguay L, Capone DG (1993) Modification of the $\mathrm{Fe}$ protein of nitrogenase in natural populations of Trichodesmium thiebautii. Appl Environ Microbiol 59:669-676

Submitted: November 3, 1998; Accepted: April 27, 1999 Proofs received from author(s): October 26, 1999 